\title{
RELACJE SEJMU USTAWODAWCZEGO Z RZĄDEM I NACZELNIKIEM PAŃSTWA: SYSTEM RZACDÓW W LATACH 1919-1922
}

\author{
RELATIONS BETWEEN THE LEGISLATIVE SEJM, \\ THE GOVERNMENT AND THE CHIEF OF STATE: \\ SYSTEM OF GOVERNANCE BETWEEN 1919 AND 1921
}

Constructing the Polish State after the First World War required establishing a system of governance enabling consolidation of the state and its authorities. Initially, the burden of establishing a provisional system of governance fell on Józef Piłsudski, who founded it on the principle of uniformity of power. In accordance with the decree of 22 November 1918, the state in statu nascendi was headed by J. Piłsudski as Provisional Chief of State, with the government subordinated to him. Piłsudski combined his office with the function of the Commander in Chief, which - in the circumstances of military conflicts accompanying the renascent Poland - strengthened his competences. The domination of the one-person organ was emphasised by the absence of a representative organ. The second stage of establishing the system of governance began with the summoning of the Legislative Sejm, which adopted the small constitution on 20 February 1919. The form of governance specified therein was also based on the principle of uniformity of power. However, it differed fundamentally from the previous one. It implemented into its structure a highly representative, but also strongly pluralised government, where no party had the majority of mandates. The Legislative Sejm had the supremacy among state organs: the government, formally subordinated to it, and the Chief of State. Because of its potentially infinite influence on the government, including co-deciding about its appointment, the Council of Ministers was made reliant on the changeable party coalitions within the Sejm. Political instability caused the works of both the Sejm and the Council of Ministers to be ineffective. The Chief of State, equipped with the competences of the Commander in Chief, politically supported by the Sejm, permanent in his opinions and consequently realizing them, steadily gained influence on shaping the policy of the state - including foreign and defence policy, as well as matters of the security of the state - taking advantage of intra-parliamentary and ministerial antagonisms. As a result, the system of governance formally based on parliament's hegemony was transformed into a more parliamentary form, with conceivable balance between the Sejm, the government subordinated to it and Chief of State. Hence, the system of governance adopted in the small constitution, although formally close to assembly governance, was distinguished with features typical for parliamentary system from before its rationalisation.

Słowa kluczowe: forma rządów, Mała Konstytucja, Sejm Ustawodawczy, Naczelnik Państwa, rząd

Key words: system of governance, small constitution, Legislative Sejm, Chief of State, government

* Dr hab. Andrzej Kulig, prof. Uniwersytetu Jagiellońskiego, andrzej.kulig@uj.edu.pl 


\section{WPROWADZENIE}

Dolska odradzająca się po ponad 100 latach niewoli stawała niemal przed samymi niewiadomymi. Odnosiły się one do tak fundamentalnych dla każdego państwa elementów jak jego terytorium, skład ludnościowy czy granice. Z nieznaną konsystencją terytorialno-ludnościową współgrała próżnia ustrojowa, w jakiej znalazło się wskrzeszone państwo. Dotychczasowe dogmaty ustrojowe, jakich nosicielami był konstytucjonalizm monarchiczny państw zaborczych, szybko się dezaktualizowały. Proponowany jeszcze w lipcu 1917 r. przez Komisję Sejmowo-Konstytucyjną Tymczasowej Rady Stanu projekt konstytucji, wzorowany na tym modelu i przygotowany z udziałem najwybitniejszych prawników polskich, dewaluował się raptownie. Jego wartość spadała wraz z postępującą klęską państw zaborczych i nadchodzącym zwycięstwem państw o ustrojach demokratycznych oraz obserwowaną radykalizacją społeczną. Kiedy w październiku i listopadzie 1918 r. pojawiły się wyraźne oznaki upadku władzy zaborczej, szybko traciły swój — i tak nikły — autorytet struktury quasi-państwowe powołane z woli okupantów. Rada Stanu rozwiązana została 7 października 1918 r. przez Radę Regencyjna, podobnie jak niecały miesiąc później Rada Ministrów pod kierunkiem Józefa Świeżyńskiego. Podjęto też próby uchwycenia suwerennej władzy na obszarze wyzwalającej się Polski. Miały one charakter z reguły lokalny, nigdy nie obejmowały nawet całości ziem poszczególnych zaborów ${ }^{1}$.

Ostateczny upadek systemu organów o charakterze quasi-państwowym działających z woli okupantów nastapił 14 listopada 1918 r., gdy Rada Regencyjna rozwiązała się, składając — jak nazwała w swym orędziu — „obowiązki i odpowiedzialność względem narodu polskiego" Józefowi Piłsudskiemu jako Naczelnemu Dowódcy, w celu przekazania rządowi narodowemu. W ten sposób stan faktycznej próżni ustrojowej został symbolicznie potwierdzony, a jednocześnie rozpoczął się proces kondensacji władzy państwowej na ziemiach polskich wokół J. Piłsudskiego². Ten moment często wskazywany jest w literaturze jako rozpoczęcie okresu dyktatury Piłsudskie$\mathrm{go}^{3}$. Pogląd ten wydaje się dyskusyjny, jeśli jednak go przyjąć, to warto wskazać na kilka okoliczności pozwalających dostrzec jej pełny kontekst ${ }^{4}$. Po pierwsze, objęcie

${ }^{1}$ Szerzej J. Pajewski, Budowa Drugiej Rzeczypospolitej 1918-1926, Poznań 2007, s. 38.

${ }^{2}$ Znamienne jest, że Rada Regencyjna w pierwszych zdaniach swego orędzia stwierdziła, że „stan przejściowy podziału zwierzchniej władzy państwowej, ustanowiony odezwą z dnia 11 listopada 1918 roku, nie może trwać bez szkody dla powstającego Państwa Polskiego. Władza ta powinna być jednolita". Choć zarówno sama Rada, jak i jej akty miały już symboliczne znaczenie polityczne, dostrzec w tym stwierdzeniu można uznanie formującego się nowego ośrodka realnej władzy.

${ }^{3}$ W. Komarnicki, Polskie prawo polityczne, Warszawa 1922, s. 52, który choć konsekwentnie używa tego określenia, to jednak wraz z wydaniem przez Tymczasowego Naczelnika Państwa dekretu z 28 listopada 1918 r. - ordynacja wyborcza do Sejmu Ustawodawczego oraz dekretu o wyborach do Sejmu Ustawodawczego, uznał, że stworzone w ten sposób podstawy organizacyjne wyborów oraz skonkretyzowany krąg obywateli uprawnionych do głosowania odjęły Polsce ,cechy państwa o ustroju tymczasowo absolutystycznym”. Confer Z. Witkowski, Prezydent Rzeczypospolitej Polskiej 1921-1935, Warszawa-Poznań 1987, s. 17.

${ }^{4}$ Confer A. Ajnenkiel, Spór o model parlamentaryzmu polskiego do roku 1926, Warszawa 1972, s. 176, idem, Parlamentaryzm II Rzeczypospolitej, Warszawa 1975, s. 106. Z kolei M. Bobrzyński w pracy Wskrze- 
władzy przez J. Piłsudskiego nastapiło wtedy, gdy brakowało ośrodka mającego zdolność objęcia władzy na całym obszarze odradzającego się państwa. Ani Polska Komisja Likwidacyjna, ani rząd lubelski, ani Rada Regencyjna i znajdujący się w faktycznej rozsypce rząd warszawski ${ }^{5}$, ale też inne podmioty tworzące się w wymiarze lokalnym nie spotykały się z ogólnonarodowym uznaniem i albo nie przejawiły ambicji do podjęcia działań na skalę odradzającego się państwa, albo spotykały się z odmową współpracy, a niekiedy wręcz były zwalczane. Na tym tle J. Piłsudski nie rysował się jako całkowicie neutralny i powszechnie akceptowany formator centralnego ośrodka władzy ${ }^{6}$. Jednak przemawiała za nim nie tylko legenda pierwszego, który przystapił do czynnej walki o niepodległość oraz więźnia niemieckiego zaborcy, ale także opinia dowódcy wojskowego, który w istniejących okolicznościach walki o wszystkie granice i wobec obecności armii niemieckiej na ziemiach polskich mógł jako jedyny wziąć na siebie ciężar zadań najpilniejszych z punktu widzenia egzystencji państwa — zapewnienia jego bezpieczeństwa zewnętrznego i wewnętrznego ${ }^{7}$. Świadomość tej roli Piłsudskiego będzie towarzyszyć kręgom politycznym, ale przede wszystkim opinii publicznej w następnych latach, a przejawiać się będzie prawnie wiążąco również w uchwałach Sejmu Ustawodawczego [dalej: SU] ${ }^{8}$. Mimo zróżnicowania społecznego w skali akceptacji dla osoby J. Piłsudskiego, licząca się jego część miała świadomość, że w najbliższym trudnym do konkretyzacji czasie sprawowanie przez niego władzy państwowej jest ultima ratio odradzającej się Polski.

Po drugie, przejmowanie władzy przez Tymczasowego Naczelnika Państwa odbywało się w warunkach władzy „leżącej na ulicy”, której los mógł pod wpływem radykalizacji społecznej przerodzić się w chaos lub zamieszki.

Po trzecie, wraz z ustapieniem Rady Regencyjnej, podporządkowaniem się innych ośrodków lub ich atrofią, Piłsudski jeszcze 14 listopada 1918 r. publicznie poddał swą władzę samoograniczeniu w zakresie podmiotowym, przedmiotowym i czasowym. W wydanym zaraz po ustapieniu Rady Regencyjnej dekrecie z dnia 14 listopada

szenie państwa polskiego. Szkic historyczny, t. II, Kraków 1920, s. 22 wskazał: „Organizacja naczelnej władzy, krótka i jasna, nadawała jej formę dyktatury powierzonej Piłsudskiemu do czasu zebrania się Sejmu, ale nie nadała jej treści”. W dalszej zaś części (s. 36) ten sam autor stwierdził: „Naczelnik Państwa dzierżył nad krajem władzę, oparty na społeczeństwie".

${ }^{5}$ Ostatnie posiedzenie rządu J. Świeżyńskiego o składzie zdominowanym przez przedstawicieli endecji, powołanego przez Radę Regencyjna, odbyło się 3 listopada 1918 r., ale po próbie obalenia Rady Regencyjnej został przez nią zdymisjonowany. Od tej pory funkcjonowało już tylko ciało noszące nazwę Rady Kierowników Ministerstw, które nie podjęło szerszej aktywności.

${ }^{6}$ Confer A. Ajnenkiel, Sejm jako czynnik integracji narodu i państwa, [w:] Sejmy Drugiej Rzeczypospolitej, red. A. Zakrzewski, Warszawa 1990, s. 25. Inaczej D. Górecki, Powstanie władz naczelnych w odradzajacej się Polsce (1914-1919), „Acta Universitatis Lodziensis. Folia Iuridica” 1983, nr 13, s. 151 i n. i cyt. tam literatura.

7 W dekrecie z dnia 14 listopada 1918 r., pierwszym akcie wydanym po rezygnacji Rady Regencyjnej, J. Piłsudski, jeszcze jako Naczelny Dowódca, stwierdził m.in.: ,Wyszedłszy z niemieckiej niewoli, zastałem wyzwalającą się Polskę w najbardziej chaotycznych stosunkach wewnętrznych i zewnętrznych, wobec zadań niezmiernie trudnych, w których lud polski sam musi wykazać swoją zdolność organizacyjną, bo żadna siła z zewnątrz nie może mu jej narzucić. Uważałem za swój obowiązek ułatwić ludowi pracę organizowania się [...]".

${ }^{8}$ J. Pajewski, op. cit., s. 36 i n. 
1918 r., ujętym w formie odezwy, a nie aktu normatywnego — co metaforycznie korelowało z państwem, znajdującym się in statu nascendi — podtrzymał wcześniej artykułowaną publicznie wolę szybkiego zwołania SU, w którym upatrywał ,jedynego twórcę praw narodu” i zaznaczał konieczność jego zwołania „w możliwie krótkim, kilkumiesięcznym terminie", co rzeczywiście nastapiło w niecałe trzy miesiące. Ponadto wskazywał, że „,z natury położenia Polski” nowy rząd będzie miał przejściowy charakter, ograniczając jego egzystencję do momentu zwołania posiedzenia Sejmu. Akcentując „prowizoryczny” charakter gabinetu, podkreślał brak zarówno jego, jak i własnej szerokiej legitymacji demokratycznej do sprawowania władzy. Z tego też względu w dekrecie (odezwie) przesądzał, że sytuacja ta ,nie dozwala na przeprowadzenie głębokich zmian społecznych, które uchwalić może tylko Sejm Ustawodawczy". Jest oczywiste, że do przyjęcia tego stanowiska skłaniały J. Piłsudskiego motywy polityczne wyrastające z przekonania, że nie powinien wiązać się z żadnym ugrupowaniem politycznym (szczególnie, że ich faktyczne wpływy polityczne były niewiadoma), a raczej stać ponad nimi. Jednak w przekonaniu tym równie wyraźnie można dostrzec samoograniczenie zakresu rodzącej się pod jego auspicjami tymczasowej władzy, że kluczowe decyzje odnoszące się także do ustroju społecznego powinny być wynikiem prac podjętych przez reprezentację narodu.

Zobowiązując prezydenta Ministrów, aby „przedłożył projekt utworzenia najwyższej władzy reprezentacyjnej Republiki Polskiej, aż do czasu zwołania Sejmu Ustawodawczego, obejmującej wszystkie trzy zabory" Piłsudski wskazał, że regulacja ta będzie miała charakter prowizoryczny, obowiązujący do czasu zwołania SU. Gabinetowi przekazał „liczne uwagi i programowe żądania otrzymane od stronnictw politycznych", których przedstawiciele intensywnie wizytowali go od powrotu z Magdeburga. Wydaje się, że już wtedy zaznaczał się wyraźny podział priorytetów J. Piłsudskiego, który z bezpośredniego, systematycznego udziału w procesie rządzenia wybrał dla siebie kluczowe zakresy: wykuwanie obszaru terytorialnego tworzącego się państwa, obronę jego egzystencji oraz wpływanie na politykę zagraniczną przy jednoczesnej rezygnacji z bezpośredniego wpływu na szereg innych dziedzin życia, jak choćby odbudowa administracji, gospodarki czy stabilizacja finansów.

Zgodnie z tą zapowiedzią 22 listopada 1918 r. rząd pod kierunkiem Jędrzeja Moraczewskiego przedłożył J. Piłsudskiemu projekt dekretu „,o najwyższej władzy reprezentacyjnej Republiki Polskiej”, który został przez niego zatwierdzony. Ze względu na fakt, że była to pierwsza, wolna od ingerencji zaborców regulacja zawierająca podstawowe normy ustrojowe tworzącego się państwa polskiego, przydaje się jej rangę konstytucyjna. Przejściowy charakter tej regulacji wyraźnie zaznaczono we wstępie, przypominając, że kresem jej obowiązywania będzie zwołanie SU. W dekrecie tym J. Piłsudski oznajmiał, że objął najwyższą władzę państwową jako Tymczasowy Naczelnik Państwa. Dekret określał kompetencje tymczasowej głowy państwa w zakresie ustawodawstwa oraz wobec rządu i tworzącego się aparatu państwowego. W pierwszym obszarze do jego kompetencji należało zatwierdzanie aktów ustawodawczych uchwalanych przez Radę Ministrów, które - co do zasady — miały obowiązywać po 
ich publikacji, jeśli w przyjętych aktach nie proponowano innego terminu ich wejścia. Jednocześnie ustalał, że akty te - podpisywane przez Naczelnika za kontrasygnatą prezydenta Ministrów — zostaną przedłożone Sejmowi na pierwszym posiedzeniu pod groźbą utraty ich mocy.

W sferze odnoszącej się do rządu i innych organów Tymczasowy Naczelnik miał zagwarantowane uprawnienia do powoływania Rady Ministrów, a tym samym i jego poszczególnych członków, a praktyka dodała w tym względzie także kompetencję do ich odwoływania. Podobnie rzecz miała się z mianowaniem wyższych urzędników państwowych, zastrzeżonych „w myśl przepisów dotychczasowych Głowie Państwa”, których Naczelnik powoływał na podstawie propozycji prezydenta Ministrów i właściwego ministra9. W dekrecie z 22 listopada 1918 r. poświęcono także uwagę Radzie Ministrów, nazywanej w tym akcie również rządem, składającej się z ministrów wraz z ich prezydentem. Wszyscy członkowie rządu ponosili odpowiedzialność przed Tymczasowym Naczelnikiem Państwa do czasu zebrania się Sejmu. Rząd dysponował kompetencją do uchwalania projektów ustawodawczych i ich przedkładania J. Piłsudskiemu do zatwierdzenia. Objęło to też budżet, który po uchwaleniu przez rząd na pierwszy okres budżetowy podlegał jego zatwierdzeniu. Dekret nie ingerował w zasady organizacji polskiego sądownictwa, które stopniowo kształtowało się jeszcze w końcowym okresie zaborów. Jedyną, acz symboliczną korektą, był nakaz wyrokowania przez sądy w imieniu Republiki Polskiej.

Pozycja Tymczasowego Naczelnika Państwa z formalno-prawnego punktu widzenia była normatywną kontynuacją stanu faktycznie wytworzonego co najmniej od 14 listopada 1918 r., a w istocie rzeczy klarującego się od powrotu J. Piłsudskiego do Warszawy, gdy na różne sposoby ujawniała się jego przywódcza rola. O ile dekret (orędzie) z 14 listopada miało charakter ad personam, to w świetle dekretu z 22 listopada jego autor ujawnił się jako Tymczasowy Naczelnik Państwa, na którego drogą faktów dokonujących się od powrotu z Magdeburga wyrastał wraz z ustępowaniem innych ośrodków ${ }^{10}$. Fakt, że w dekrecie nie wspomniano ani słowem o sile zbrojnej, skupiając się na organizacji - co prawda w szczątkowej formie - centralnego aparatu państwa, oznaczał, że nastapiło rozdzielenie dwóch ról ustrojowych J. Piłsudskiego — zwierzchnika państwa oraz naczelnego dowódcy (którego zakres kompetencji i relacje z władzą cywilną zostały pominięte). Dualizm tu normatywnie zapoczątkowany będzie kontynuowany przez kilka następnych lat, mimo istotnie zmienionych uwarunkowań ustrojowych.

We wprowadzonym systemie organów państwowych można dostrzec kilka cech charakterystycznych. Po pierwsze, wyraźna jest tymczasowość wytworzonego układu. Wskazywał na to fakt, że dekret ściśle wiązał się z osobą J. Piłsudskiego, personi-

${ }_{9}$ W istocie było to zakamuflowane odwołanie się do art. 31 dekretu Rady Regencyjnej z 3 stycznia 1918 r. o tymczasowej organizacji Władz Naczelnych w Królestwie Polskiem (Dziennik Praw Królestwa Polskiego z 1918 r. nr 5, poz. 8), określającego uprawnienia w tym zakresie Rady Regencyjnej.

${ }^{10}$ Stąd też zasadne jest stwierdzenie, że dla ukonstytuowania władzy J. Piłsudskiego dekret z 22 listopada 1918 r. miał charakter deklaratoryjny. Inaczej T. Ciświcki, O Naczelniku Państwa i Prezydencie Rzeczypospolitej Polskiej. Studium prawno-polityczne, Poznań 1922, s. 14. 
fikując w jego postaci urząd Tymczasowego Naczelnika Państwa. Wyrażało się to także w zwrotach językowych w nim zawartych, przede wszystkim pisanych w trybie oznajmującym, w pierwszej osobie liczby pojedynczej (np. stanowię, co następuje, obejmuję) lub w dopełnieniu wyrażonym zaimkiem przymiotnym „mój” (ulegają mojemu zatwierdzeniu ). Dekret limituje czasowo jego władzę nie tylko poprzez pierwszy człon nazwy organu, ale również wskazanie, że jej kres wyznacza zwołanie SU. Oznaczało to, że z tą chwilą może się zmienić zarówno forma rządów, jak i pozycja Tymczasowego Naczelnika Państwa i podporządkowanego mu rządu. Było to wysoce prawdopodobne, zważywszy, że większość sił politycznych od wielu miesięcy wyrażała konieczność zwołania pierwszej ogólnonarodowej reprezentacji parlamentarnej, wiążąc $\mathrm{z}$ tym organem zasadnicze decyzje ustrojowe ${ }^{11}$. W odniesieniu do rządu potwierdzało to orędzie J. Moraczewskiego z 20 listopada 1919 r., które stanowiło, że rząd ma charakter tymczasowy, a jego misja zakończy się wraz ze zwołaniem SU.

Po drugie, cechą rodzącego się systemu organów państwowych jest fragmentaryczność jego regulacji normami o charakterze konstytucyjnym. Tworzące go organy zostały zarysowane cząstkowo i niepełnie (pominięto przede wszystkim sądownictwo), co odnosi się także do określenia zakresu ich działania. Brakuje jakiegokolwiek odniesienia się do kwestii budowy pozostałego aparatu państwa, jego relacji z rządem lub Naczelnikiem, natomiast zakres kompetencji obu organów ujęty był niezwykle wąsko, w dużym stopniu skupiając się na wzajemnym stosunku oraz ich udziale w ustawodawstwie. Jest to zrozumiałe, gdyż mimo wyraźnej intencji objęcia rodzącą się władzą państwową ogółu ziem polskich ${ }^{12}$, zakres zadań i kompetencji do ich realizacji przyznanych organom tworzącego się państwa ulegał dopiero stopniowej krystalizacji w nadchodzących latach, gdy uświadamiano sobie skalę różnych problemów koniecznych do rozwiązania w nowo tworzącym się państwie. Ponadto w praktyce ustrojowej okazało się, że niektóre regulacje pochodzące $\mathrm{z}$ okresu rządów Rady Regencyjnej będą miały zastosowanie nadal, stając się techniczno-wykonawczym rozwinięciem reguł generalnie określonych $\mathrm{w}$ dekrecie czy aktach konstytucyjnych powstałych w następnych latach. Dotyczyło to m.in. organizacji prac rządu i ministrów, a także zakresu ich właściwości czy tworzenia nowych organów i instytucji publicznych, określonych m.in. w dekrecie Rady Regencyjnej z 3 stycznia 1918 r.

Mimo szczątkowego charakteru regulacji, można wskazać, że pierwsze unormowanie o charakterze konstytucyjnym pozwalało potraktować zarówno Tymczasowego Naczelnika Państwa, jak i Radę Ministrów jako dwa odrębne organy państwowe. Przemawiają za tym - określone w sposób dalece niepełny z perspektywy współczesnych standardów — zawarte w dekrecie z 22 listopada 1918 r. postanowienia odnoszące się do kompetencji i zadań obu tych organów, jak i określenie ich obsady perso-

${ }^{11}$ Jedyną, choć istotna, siłą polityczną niechętnie nastawioną do zwołania Sejmu była endecja, co czyniła głównie ze względów taktycznych, obawiając się (jak się miało okazać, niesłusznie), że na kanwie radykalizacji społecznej jej reprezentacja parlamentarna może w niewystarczającym stopniu odzwierciedlać wpływy społeczne.

${ }^{12}$ Dekret z 14 listopada 1918 r. Naczelnego Dowódcy wskazywał na obszar trzech zaborów, co tworzyło szerokie ramy dla określenia przyszłych granic państwa polskiego. 
nalnej. Co interesujące, o ile w okresie rządów Rady Regencyjnej istniała wspólna formuła działania Rady i Rady Ministrów w postaci Rady Koronnej, to brak takiej instytucji w dekrecie z 22 listopada 1918 r. podkreślał tę odrębność. Piłsudski zrezygnował z zajmowania stanowiska ministra spraw wojskowych w kolejnych rządach i co znamienne - nie powołując nikogo na to stanowisko, co podkreślało zarówno rozdzielność obu organów, jak i wyraźną autonomizację problematyki dowodzenia wobec prac rządowych.

Po trzecie, nie budzi wattpliwości zwierzchnia pozycja Tymczasowego Naczelnika Państwa. Jest to zwierzchność w rodzącym się systemie organów państwowych, a wspomniana w dekrecie „najwyższa władza”, powinna być odnoszona do usytuowania Tymczasowego Naczelnika względem pozostałych organów. Zwierzchność ta jednak napotykała ograniczenia. W pierwszej kolejności była ona ograniczona odrębnością sądownictwa, którego niezależność nie była modelowa, lecz pozostawała poza bezpośrednim wpływem Tymczasowego Naczelnika Państwa. W stosunku do Rady Ministrów jego pozycję wyznaczała odpowiedzialność polityczna ponoszona przez rząd przed Naczelnikiem, a w konsekwencji swoboda kształtowania jego składu. Jednak jak się szybko okazało, zarówno ostatecznie niepowołany rząd Ignacego Daszyńskiego, jak i rządy J. Moraczewskiego oraz Ignacego J. Paderewskiego powstawały pod wpływem układu politycznego kształtującego się u zarania II RP w różnym, ale zwiększającym się stopniu systematycznie uwzględnianym przez Piłsudskiego. Tymczasowy Naczelnik Państwa dysponował możliwością zablokowania projektów ustawodawczych przygotowanych przez Radę Ministrów bez względu na to, czy stały za tym racje polityczne, prawne czy też innej proweniencji. Zwierzchność Naczelnika Państwa, choć wyraźna i ujawniająca się w praktyce politycznej tego okresu, nie oznaczała jednak braku samodzielności Rady Ministrów ${ }^{13}$. W praktyce kolejne rządy podejmowały większość decyzji bez ingerencji Tymczasowego Naczelnika, a nawet poza jego świadomością, oczywiście jeśli były podejmowane w formie prawnej innej niż dekrety ${ }^{14}$. Działalność kolejnych rządów pokazała, że większość ich zadań związanych była z mozołem permanentnego zarządzania kryzysowego, skupiającego się na podstawowych potrzebach egzystencjalnych obywateli i państwa, które pozostając w generalnej optyce J. Piłsudskiego nie zdominowały jego

13 Podobnie P. Sarnecki, Zasady ustrojowe odradzajacej się Polski, „Przegląd Sejmowy” 1998, nr 5, s. $35-36$.

14 Jest rzeczą ciekawa, że dekrety przedstawione na pierwszym posiedzeniu SU zostały podzielone na grupy zgodnie z zakresem przedmiotowym działania danego ministra (np. Ministerstwo Spraw Wewnętrznych przedłożyło 34 dekrety, Ministerstwo Skarbu - 22 dekrety), a nie en bloc przez rząd lub szefa rządu. Prezydent Ministrów przedstawił 10 dekretów, w tym dwa ustanowione przez Radę Regencyjną. Dekrety te miały z reguły charakter generalny, dotycząc powołania urzędów (np. utworzenia kancelarii cywilnej Naczelnika Państwa, Ministerstwa Sztuki i Kultury), czy ustrojowy (np. dekret o najwyższej władzy reprezentacyjnej Republiki Polskiej czy dotyczący nadania statutu Komisji Rządzącej dla Galicji i Śląska Cieszyńskiego oraz Górnej Orawy i Spiżu). Podział dekretów przedstawiony SU nie był zawsze konsekwentny, gdyż dekret o ordynacji wyborczej do SU, choć miał ogólnoustrojowe znaczenie, znalazł się w puli dekretów przekazanych przez Ministerstwo Spraw Wewnętrznych ze względu na fakt, że został przygotowany przez to ministerstwo. Łącznie przedłożono w trakcie pierwszego posiedzenia konstytuanty 210 dekretów. Confer także S. Krukowski, Mała Konstytucja z 1919 r., [w:] Konstytucje Polski, red. M. Kallas, Warszawa 1990, s. 8-9. 
wysiłków na rzecz utrzymania niepodległości państwa na drodze dyplomatycznej, jak i militarnej ${ }^{15}$.

Józef Piłsudski jako Tymczasowy Naczelnik Państwa nie predestynował do roli suwerena. O ile był organem zwierzchnim (z zastrzeżeniem faktycznej pozycji sądownictwa) wobec innych organów, także sił zbrojnych, o tyle uznawał w sposób oczywisty suwerenność narodu ${ }^{16}$, traktując wytworzony stan jako przejściowy — fazę pośrednią w prawnej materializacji zasady suwerenności narodu via wybory i ukonstytuowanie się SU. Potwierdziło to także orędzie J. Moraczewskiego z 20 listopada 1918 r. i to zarówno gdy chodzi o jego formę, jak i samą treść. Wystosowane przed ogłoszeniem dekretu o najwyższej władzy reprezentacyjnej było swoistym exposé programowym ${ }^{17}$, które w zwykłych okolicznościach rząd parlamentarny — w różnej postaci — przedkłada reprezentacji narodu na początku swej drogi. Wobec braku tej reprezentacji orędzie to pod tytułem „Do narodu polskiego” kierowano bezpośrednio do suwerena, tym samym uznając go za pierwotne źródło władzy państwowej. Nie budziło wątpliwości, że organy państwa wskazane $\mathrm{w}$ dekrecie z 22 listopada $1918 \mathrm{r}$. funkcjonowały z przeświadczeniem ograniczonego charakteru swej legitymacji oraz zakładając związanie zasadą suwerenności narodu ${ }^{18}$.

Próbując odpowiedzieć na pytanie o system rządów, którego ucieleśnieniem był układ wytworzony w pierwszych miesiącach niepodległości Polski, należy uwzględnić kontekst historyczny jego formowania się. Niepodległość została dana Polsce w warunkach przez większość nieoczekiwanych. Jeszcze w pierwszych latach wojny duża część sił politycznych wiązała się współpracą z zaborcami, licząc raczej na ograniczoną zmianę statusu ziem polskich niż na pełną suwerenność państwową. Skala i przebieg wojny czyniły z upływem czasu wizję niepodległości państwa polskiego coraz bardziej realna, ale jej kształt ustrojowy był nadal nieskonkretyzowany. Formujący się prowizoryczny system rządów był wypadkową lawiny nieprzewidywalnych wydarzeń oraz okoliczności, których planowanie nie było możliwe. Stąd należy ocenić to rozwiązanie jako przynoszące minimalny ład organizacyjny, pozwalający uniknać chaosu i anarchii. Wytworzony pod presją chwili i bez wcześniej wypracowanych założeń, przyjęty został z intencją możliwe sprawnego sprostania najważniejszym zadaniom stojącym przed formującym się państwem. Stąd też zwierzchnia wobec innych tworzacych się form organizacyjnych rola organu jednoosobowego (co prima facie może przypominać dyktaturę) i koncentracja na organach o charakterze zarządzającym, działającym na podstawie samodzielnie tworzonego, lecz tymczasowego ustawodawstwa. Był to więc z konieczności prowizoryczny model oparty na systemie jed-

${ }^{15}$ Confer J. Goclon, Rzad Jędrzeja Moraczewskiego 17 XI 1918-16 I 1919 (struktura, funkcjonowanie, dekrety), „Przegląd Nauk Historycznych” 2009, nr 2, s. 99 i n.; idem, Rzad Ignacego Jana Paderewskiego. Geneza, skład osobowy i dzialalność (16 stycznia 1919-9 grudnia 1919 r.), „Acta Universitatis Lodziensis. Folia Historica" 2011, nr 86, s. 93 i n.

${ }^{16}$ Confer Z. Cybichowski, Polskie prawo państwowe, cz. I, Warszawa 1925, s. 205.

17 Pisano w nim m.in.: , ,...] poczuwamy się do obowiązku wyłuszczenia przed narodem naszego stanowiska, do wskazania mu dróg, któremi pójdziemy i celów jakie sobie stawiamy".

18 Confer P. Sarnecki, op. cit., s. 32. 
nolitości władzy, dla którego zwieńczeniem, a w tych okolicznościach i punktem krystalizacji był Tymczasowy Naczelnik Państwa. Jednak dojmującym jego brakiem była absencja organu przedstawicielstwa narodowego.

\section{NARODZINY NOWEGO SYSTEMU RZĄDÓW}

Wraz z zebraniem się Sejmu Ustawodawczego 10 lutego 1919 r. rozpoczął się nowy etap ewolucji ustrojowej. Formalnie z tym dniem wygasła tymczasowa regulacja ustrojowa, wprowadzona dekretem przez J. Piłsudskiego. Dominującym problemem w tych dniach było określenie pozycji ustrojowej organu przedstawicielstwa narodowego i bezpośrednio z tym powiązana konieczność odniesienia się do roli ustrojowej pozostałych organów naczelnych, tworzących prowizoryczną formę rządów. Mimo daleko zaawansowanego zróżnicowania politycznego SU, panowała w nim zgoda co do jego nadrzędnego stanowiska w systemie ustrojowym państwa ${ }^{19}$. Przyczyn takiego nastawienia było kilka, należy jednak przypomnieć, że przyznanie reprezentacji narodu zwierzchniego charakteru było pewną reguła, charakterystyczną dla państw znajdujących się w fazie gwałtownych przemian społecznych i politycznych ${ }^{20}$. Dzieje państw europejskich pokazały, że radykalizacja społeczna dla sił lewicowych i prawicowych jest silnym impulsem do formowania przedstawicielstwa narodowego o szczególnej pozycji. Oczywiście motywacje poszczególnych środowisk politycznych były z reguły odmienne, zarówno ideowe jak i czysto taktyczne, i nie inaczej było u zarania SU.

W odradzającej się Polsce idea zwołania Sejmu jako zasadniczej inauguracji jej państwowości od dłuższego czasu stała się głównym postulatem powielanym w licznych deklaracjach różnych sił politycznych i innych podmiotów ${ }^{21}$. Nawet powstały u kresu działalności Rady Regencyjnej rząd J. Świeżyńskiego, zdominowany przez endeków, punktem swego programu uczynił postulat niezwłocznego zwołania Sejmu. A gdy siły polityczne, reprezentowane w tym rządzie, za kilkanaście dni zmieniły radykalnie swój pogląd, lansując zamiast zwołania Sejmu powołanie Naczelnej Rady

${ }^{19}$ Zdawał sobie z tego sprawę J. Piłsudski, który otwierając pierwsze posiedzenie SU 10 lutego 1919 r., stwierdził m.in.: ,[...] przypadł mi zaszczyt otwierać sejm, który znowu będzie domu swego ojczystego jedynym panem i gospodarzem [...]". W tym samym wystapieniu wśród głównych zadań parlamentu wskazywał: „Obdarzeni dziś zaufaniem narodu dać mu macie podstawy dla jego niepodległego życia w postaci prawa konstytucyjnego Rzeczypospolitej Polskiej”, sprawozdanie stenograficzne z posiedzenia Sejmu Ustawodawczego" [dalej: spr. sten. z SU] z 1. posiedzenia SU, 10 lutego 1919 r., ł. 2-3.

${ }^{20}$ Podobnie Z. Witkowski, op. cit., s. 19.

${ }_{21}$ Już 17 listopada 1916 r., na zjeździe obywatelskim Ligi Państwowości Polskiej w Piotrkowie, przyjęta została rezolucja, głosząca m.in.: „Źródłem rządu i twórcą armii może być jedynie powstały na zasadzie ogólnych wyborów Sejm Polski”. W tym samym czasie podobnie wypowiedziała się PPS — Frakcja Rewolucyjna, która w swojej odezwie stwierdziła, że „O budowie wewnętrznej naszego państwa, o jego ustroju społecznym i politycznym stanowić może jedynie Sejm ustawodawczy, czyli konstytuanta wybrana przez powszechne, równe, tajne, bezpośrednie i proporcjonalne głosowanie". Jak łatwo dostrzec, echa tego sformułowania są wyraźne w stanowisku J. Piłsudskiego, zajmowanym u narodzin niepodległości. Od końca 1916 r. postulat zwołania Sejmu i zajęcia przez niego szczególnego stanowiska ustrojowego był głoszony — choć z różną motywacją — przez niemal wszystkie ugrupowania polityczne. Confer L. Hass, Do genezy złudzeń parlamentarnych w Polsce międzywojennej (Sejm i glosowanie powszechne w propagandzie politycznej Królestwa 1915-1918), „Kwartalnik Historyczny” 1972, LXXIX, z. 1, s. 56 i n. 
Narodu Polskiego, składającej się z delegatów partii politycznych z trzech zaborów, to także ten organ w planach jej twórców miał stać się zwierzchni wobec innych, likwidując przy okazji urząd Tymczasowego Naczelnika Państwa22 ${ }^{22}$ Poza jasnymi przyczynami politycznymi tego rozwiązania, zwraca uwagę fakt, że Rada, choć o wątpliwej reprezentacyjności, została wysunięta jako wiodąca w systemie rządów, co pokazuje, jak silne było przekonanie o tym, że organy traktowane jako przedstawicielskie powinny zajmować uprzywilejowaną pozycję ${ }^{23}$.

Upadek Rzeczypospolitej na skutek rozbiorów przynosił Polakom utratę ich podmiotowości politycznej, a w konsekwencji poddanie się polityce zaborców systematycznego redukowania wpływu politycznego i ekonomicznego Polaków na zamieszkiwane przez nich terytorium. Wskrzeszenie Polski przynosiło jej obywatelom odzyskanie pełni podmiotowości politycznej, w tym uzyskanie praw wyborczych w celu wyłonienia własnego przedstawicielstwa parlamentarnego ${ }^{24}$. Skoro wśród powstających centralnych organów państwowych parlament jako jedyny miał tak szczególną legitymację, naturalną rzeczą było jego wysforowanie. W ten sposób można było oznajmić powstanie nowego ładu politycznego, dla którego kluczowym spoiwem była zasada suwerenności narodu, a w konsekwencji praktyczna forma jej realizacji przez obywateli w postaci wyborów powszechnych i pochodzącego z nich najwyższego organu państwowego ${ }^{25}$. Rzeczą naturalną w ówczesnym myśleniu o roli parlamentu było, że skoro źródłem władzy jest naród, to parlament jako jego emanacja powinien mieć zagwarantowaną adekwatną pozycję w państwie. O ile w pierwszych miesiącach odzyskiwania niepodległości można uznać za dość powszechny głos opinii publicznej upatrujący w J. Piłsudskim jedyną osobę właściwą do sprawowania pełni władzy, jako nieformalnie wyrażone stanowisko suwerena, o tyle wraz z przeprowadzeniem wyborów jedynym organem czerpiącym swą władzę z wyraźnie objawionej woli suwerena stał się SU. Konstytuanta - z chwila jej wyłonienia - stała się jedynym bezpośrednim organem państwowym, kładąc kres dotychczasowej ludowej, ale domniemanej legitymacji J. Piłsudskiego. Zmieniało to diametralnie relacje w rodzącym się systemie rządów, wynosząc SU na miejsce dotąd zajmowane przez Tymczasowego Naczelnika Państwa, tego zaś przesuwając do roli, która miała zostać określona przez konstytuantę.

22 Confer M. Bobrzyński, op. cit., s. 46 i n.; A. Ajnenkiel, op. cit., s. 187 i n.

${ }^{23}$ W tym kontekście przywoływany jest przykład czechosłowackiego Narodnego Vyboru, który powołany został w drodze nominacji partii politycznych wedle klucza, jakim była liczba mandatów obsadzonych przez nie w ostatnich przedwojennych wyborach do parlamentu austriackiego w 1911 r., confer A. Ajnenkiel, op. cit., s. 187 i n.

${ }^{24}$ Problematyka kształtu wyborów do konstytuanty, w różnych wariantach, pojawiała się w dyskursie politycznym co najmniej od 1916 r., a wraz ze zbliżającym się końcem wojny światowej przechodziła fazę radykalizacji postulatów, lakonicznie ujmowanych jak wybory demokratyczne. W istocie takie się stały na mocy ordynacji z 28 listopada 1918 r., przygotowanej przez rząd J. Moraczewskiego i zatwierdzonej przez Tymczasowego Naczelnika Państwa. To sprawiło, że pierwsze w historii Polski wybory powszechne, poza walorem autentyczności wyłonionej reprezentacji, wywołały duże nadzieje związane z efektami pracy konstytuanty.

${ }_{25}$ Por. M. Pietrzak, Parlament w systemie organów państwowych, [w:] Sejmy Drugiej..., s. 57. 
Dla dużej części posłów, głównie z ugrupowań centroprawicowych, nadrzędne stanowisko Sejmu w systemie organów państwowych rozwiązywało uwierający i nie do zaakceptowania na dłuższą metę, status Naczelnika Państwa. Zmiana istniejącej konfiguracji, przy dużym autorytecie społecznym J. Piłsudskiego, mogła być uzasadniona jedynie wtedy, kiedy jego miejsce zajęło przedstawicielstwo narodowe, pochodzące $\mathrm{z}$ wyborów powszechnych i materializujące wielkie nadzieje z nim związane, wyrażane przez większość wyborców. Nie znosiło to oczywiście problemu znalezienia właściwej formuły dalszej egzystencji ustrojowej Naczelnika, ale było satysfakcjonującym dla obozu centroprawicowego, ograniczeniem jego dotychczasowego statusu i barierą dla jego emancypacji kompetencyjnej.

Dla obozu lewicy sejmowej, z reguły przyjaznej J. Piłsudskiemu, oparcie rodzącego się ustroju politycznego na zasadzie suwerenności narodu i wynikającej stąd uprzywilejowanej pozycji parlamentu było od dawna postulatem programowym ${ }^{26}$. System z pierwszoplanową pozycją parlamentu był radykalnym odcięciem się od dotąd obowiązujących na ziemiach polskich mechanizmów monarchii konstytucyjnej, dla której parlament niemal do samego końca ich istnienia nie odgrywał kluczowej roli ustrojowej. Większość polityków tego obozu, ale i sam J. Piłsudski, dostrzegała zalety deliberatywnej i integracyjnej funkcji SU, w którego pracach można było skonfrontować różne nurty polityczne i ich programy, tworząc parlamentarną większośćc ${ }^{27}$. Misja SU jako organu tworzącego nowy ład prawny, w tym konstytucję niepodległego państwa, po raz pierwszy od blisko 130 lat w sposób wolny od dyktatu państw obcych i - w założeniu — zgodny z wolą narodu, przemawiała oczywiście za nieskrępowaną, wolną od ograniczeń, pozycją reprezentacji narodowej ${ }^{28}$.

${ }^{26}$ M. Bobrzyński, op. cit., s. 50 odnosząc się do genezy małej konstytucji, uważał, że ,złożyło się na nią dążenie posłów i stronnictw ultrademokratycznych do wszechwładzy Sejmu z nieufnością narodowych demokratów do Piłsudskiego, która im podyktowała ograniczenie władzy Naczelnika Państwa”.

${ }^{27}$ W trakcie swojej przemowy w SU, składając urząd, J. Piłsudski stwierdził m.in.: „Wśród olbrzymiej zawieruchy, w której miliony ludzi rozstrzyga sprawy jedynie gwałtem i przemoca, dążyłem, by właśnie w naszej Ojczyźnie konieczne i nieuniknione tarcie społeczne były rozstrzygane w sposób jedynie demokratyczny: za pomocą praw, stanowionych przez wybrańców narodu". Z tą konstatacją dobrze koreluje instrukcja przekazana polskiej delegacji na rozmowy z Komitetem Narodowym Polskim w Paryżu i przedstawicielami państw Ententy, w której zawarto następujące tezy: „Państwo Polskie buduje się zupełnie na nowo i nie ma w nim żadnej tradycji, żadnego zwyczajowego i prawnego oparcia. Państwo nie posiada prawnych podstaw swej egzystencji i poszczególne formy jego organizacji są to właściwie ciagle stany ex lex. W tych warunkach: a) konstytuanta da krajowi pierwsze poczucie prawa dokonanego bez udziału obcych, b) konstytuanta jedynie zaważyć może przeciwko bolszewizmowi, będącemu niczym innym jak dyktaturą mniejszości, niemożliwemu zatem tam, gdzie panuje ukonstytuowana większość. Obawy nadmiernego zradykalizowania konstytuanty i przez konstytuantę kraju są z gruntu fałszywe. Konstytuantę w Polsce będzie wybierać ogromna większość chłopska, c) konstytuanta będzie jedyną formą złączenia dzielnic w jedno, wyrównania różnic między dzielnicami, faktycznego zjednoczenia Polski”, cyt. za: A. Ajnenkiel, Sejm jako czynnik..., s. 23.

${ }_{28}$ Znamienne jest tu sformułowanie zawarte w wystapieniu Tymczasowego Naczelnika Państwa na posiedzeniu SU 20 lutego 1919 r., gdy składając swój urząd, stwierdził m.in., że: ,w Polsce XX wieku źródłem praw może być jedynie Sejm, wybrany na podstawach demokratycznych". Confer także A. Ajnenkiel, Spór o model..., s. 194-195, R. Kraczkowski, Mała Konstytucja z 20 lutego 1919 r., [w:] Małe Konstytucje. Ustawy zasadnicze okresów przejściowych 1919-1947-1992, red. R. Jastrzębski. M. Zubik, Warszawa 2014. 
Wreszcie — paradoksalnie — za ważne należy uznać doświadczenie mijających miesięcy obowiązywania modelu jednolitości władzy, a w nim nadrzędności jednego organu państwowego nad pozostałymi. Zewnętrzna obserwacja działania tego modelu choć niejednoznaczna i spotykająca się z krytyką zarówno Naczelnika Państwa, jak i podporządkowanego mu rządu miała jednak dwa istotne walory. Była pierwszą doświadczoną na wyzwalającym się obszarze Polski formą rządów, poznaną - co prawda - dość powierzchownie, nierozwiniętą w pełnym zakresie ze względu na skrajnie trudne warunki, jednak konsolidującą władzę państwową. Usytuowanie Sejmu w miejscu zajmowanym dotąd przez Naczelnika Państwa mogło być uważane za udoskonalenie dotychczasowej formy rządów, gdyż zastępowało jednoosobowość — kolegialnością, wyrażającą przy tym wielopartyjność właściwą parlamentarnemu przedstawicielstwu. Dawało to podstawy do przypuszczeń, że poszczególne ugrupowania reprezentowane w Sejmie uzyskają wpływ na dalszy rozwój wypadków, w tym znajdujące się na porządku dziennym kwestie ustrojowe, społeczne czy gospodarcze, dotyczące m.in. reformy rolnej, relacji między pracodawcą a pracownikami, problemów narodowościowych i szeregu innych palących kwestii.

Wielu stronnictwom towarzyszyła nadzieja, że możliwe jest stworzenie większości parlamentarnej, która uzyska dzięki pozycji SU dominujący wpływ na kluczowe rozstrzygnięcia polityczne i ustrojowe. Sejm przy swojej zwierzchniej pozycji jawił się jako arena rywalizacji o zdobycie pełnej władzy w państwie i podporządkowanie sobie innych organów państwowych. Inna rzecz, że to co u początków konstytuanty wydawało się całkiem realne, $\mathrm{z}$ biegiem czasu okazało się jedynie mirażem. W tym stanie rzeczy, mimo różnicy generalnych zapatrywań na przyszły kształt ustrojowy Polski oraz docelowy system rządów, występująca między ugrupowaniami parlamentarnymi kwestia nowej formy rządów została zdecydowana sprawnie, choć w sposób stosunkowo oryginalny. Wobec świadomości wszystkich ugrupowań, że przyjęcie nowej konstytucji może trwać dłużej (choć nikt nie przewidywał, że zajmie to ponad dwa lata ${ }^{29}$, zdecydowano się na rozwiązanie przejściowe, podobnie jak w listopadzie 1918 r. uczynił to J. Piłsudski.

\section{FORMA RZĄDÓW WEDLUG MALEJ KONSTYTUCJI}

Projekt kolejnego prowizorium był przedmiotem krótkotrwałych obrad Konwentu Seniorów. Organ ten powstał samorzutnie, jeszcze przed przyjęciem Tymczasowe-

${ }^{29} \mathrm{~W}$ protokole z posiedzenia Konwentu Seniorów stwierdzono, że m.in. ,[...] ze względu na anormalny stan jaki wytwarza łączenie w rękach jednej osoby najwyższej władzy cywilnej i wojskowej [co było oczywistym dostrzeżeniem ról pełnionych przez J. Piłsudskiego - uwaga A.K.] postanowiono protokólarnie stwierdzić, że projekty konstytucji po pierwszym czytaniu, które może się ciaggnąć najdalej przez trzy posiedzenia, będą odesłane do Komisji Konstytucyjnej z poleceniem przedłożenia sprawozdania o organizacji naczelnych władz w Państwie Polskim najdalej w ciagu trzech tygodni, tak iżby powyższe tymczasowe zasady Konstytucji mogły być uchwalone najdalej w ciagu czterech tygodni.”, cyt. za: S. Krukowski, op. cit., s. 12. Jak wiadomo, był to przejaw katatymii dającej się usprawiedliwić szczególnym momentem historycznym. W praktyce prace nad konstytucją rozpoczęły się w połowie 1919 r., zakończyły 17 marca 1921 r., zaś sama konstytucja wchodziła w życie do grudnia $1922 \mathrm{r}$. 
go Regulaminu obrad Sejmu ${ }^{30}$. Stanowił reprezentację klubów sejmowych liczących co najmniej 12 posłów, a w jego skład wchodzili przedstawiciele każdego klubu w liczbie wynikającej z wielokrotności liczby 12, mieszczącej się w ogólnej liczbie posłów tego klubu. Podstawą prac tego wąskiego gremium stał się wniosek przedstawiony formalnie 19 lutego 1919 r. przez Franciszka Bardla, posła PSL „Piast”, a który nie stał się nawet oficjalnym drukiem sejmowym. Po krótkiej dyskusji wniosek ten przyjął formę projektu uchwały SU i uzyskał niemal jednomyślne poparcie, które wyraziło się już w oficjalnym wniosku złożonym następnego dnia na posiedzeniu Sejmu, podpisanym przez ponad stu kilkudziesięciu posłów, w tym liderów wszystkich klubów sejmowych, jak posłowie: Wojciech Korfanty, Wincenty Witos, Ignacy Daszyński, Błażej Stolarski, Józef Ostachowski, Bolesław Fichna i Stanisław Chaniewski ${ }^{31}$.

Nim to jednak nastapiło, 20 lutego 1919 r. przed Sejmem wystapił J. Piłsudski, który powołując się na prowizoryczny charakter rządów dotąd sprawowanych oraz dopełniając zobowiązanie zawarte w dekrecie z 22 listopada 1918 r., złożył swój urząd. Następnie został przedstawiony przez marszałka Sejmu Wojciecha Trąmpczyńskiego jako nagły, wspomniany wniosek poselski i zgodnie z jego sugestia, uchwała ta została niezwłocznie przyjęta, bez dyskusji i przez aklamację, otrzymując tytuł o powierzeniu Józefowi Piłsudskiemu dalszego sprawowania urzędu Naczelnika Państwa ${ }^{32}$. Ze względu na swoje fundamentalne znaczenie ustrojowe zyskała miano małej konstytucji, choć ani forma tego aktu prawnego, ani jej tytuł nie skłaniały do tego - uchwała Sejmu z dnia 20 lutego 1919 r. o powierzeniu Józefowi Piłsudskiemu dalszego sprawowania urzędu Naczelnika Państwa [dalej: mała konstytucja] ${ }^{33}$. Przyjęcie projektu przez nieformalne ciało parlamentarne, a następnie jego uchwalenie nastapiło również, jak na akt konstytucyjny, w sposób wyjątkowy. Jednak stała się ona zasadniczym aktem dla określenia formy rządów w państwie polskim na — jak się okazało — blisko cztery lata.

Mała konstytucja od strony konstrukcyjnej składała się z dwóch części. Pierwsza była swego rodzaju bilansem dotychczasowej aktywności J. Piłsudskiego, rozliczającym okres sprawowania przez niego władzy. Dokonało się to w formule jednoczesnego przyjęcia jego oświadczenia o złożeniu urzędu oraz ponownym mu go powierzeniem (to rozstrzygniecie obwieszczono już w II części uchwały). Wacław Komarnicki nazywa to wprost udzieleniem J. Piłsudskiemu przez SU wotum zaufania za okres poprzednich rządów, choć w samej uchwale takie pojęcie nie padło ${ }^{34}$. Sam Piłsudski bowiem ustalił kres swego urzędu w obu wspomnianych dekretach listopadowych na moment zebrania się SU i pomijał w nich swoją odpowiedzialność polityczną (w formie

${ }^{30}$ A. Ajnenkiel, Historia sejmu polskiego, Warszawa 1989, t. II, cz. 2, s. 35.

31 Szerzej na ten temat W.T. Kulesza, Uchwała Sejmu Ustawodawczego z dnia 20 lutego 1919 r. o powierzeniu Józefowi Piłsudskiemu dalszego sprawowania urzędu Naczelnika Państwa, „Przegląd Sejmowy” 2007, nr 5, s. 38 i n. i cyt. tam literatura.

32 Dz.P.P.P. z 1919 nr 19, poz. 226.

33 Warto jednak pamiętać, że w tym okresie terminologia stosowana dla nazwania aktów normatywnych uchwalanych przez SU nie była jeszcze ostatecznie ukształtowana. Pojawiały się m.in. określenia: ustawa tymczasowa (z dnia 2 sierpnia 1919 r. o organizacji władz administracyjnych II instancji), ustawa zasadnicza (zasadnicza ustawa sanitarna z dnia 19 lipca 1919 r.).

34 W. Komarnicki, op. cit., s. 65. 
parlamentarnej) za ten okres. Zamknięcie tego epizodu ustrojowego miało się dokonać wedle Naczelnika Państwa na drodze czysto mechanicznej, bez jakiejkolwiek prawnej formy jego rozliczenia ${ }^{35}$. Jedynym podmiotem ponoszącym odpowiedzialność parlamentarną za jego działania był rząd, przejmujący ją w drodze kontrasygnaty, co czyniło ją bezprzedmiotową w stosunku do Piłsudskiego. Przy przyjęciu koncepcji W. Komarnickiego, że działania naczelnych organów państwowych sprzed ukonstytuowania się SU również podlegały odpowiedzialności parlamentarnej, to właśnie podstawę prawną do tego rodzaju działań — i tylko wobec Rady Ministrów — stanowiła instytucja kontrasygnaty, przewidziana w dekrecie z 22 listopada $1918 \mathrm{r}^{36}$ Jednak ten sam autor stwierdził, że instytucja ta nie stanowiła ,istotnej gwarancji prawnopolitycznej” i nie odgrywała tej roli, ,co przy systemie wyłącznej odpowiedzialności rządu, lub nawet wspólnej odpowiedzialności obu czynników (Naczelnika Państwa i rządu)"37. Jeśli zgodzić się z opinią W. Komarnickiego, że jednym ze skutków małej konstytucji było swoiste wotum zaufania, to należy w nim dostrzegać działanie SU pro futuro jako inaugurację nowego systemu rządów, w którym obowiązuje zasada, uzależniająca powołanie i działalność Naczelnika Państwa oraz Rady Ministrów od woli ciała parlamentarnego. W tym znaczeniu wspomniane przez W. Komarnickiego wotum zaufania było nadaniem przez SU inwestytury Naczelnikowi Państwa, dla którego źródłem sprawowanej władzy — inaczej niż do tej pory — była wola wyrażona przez parlament.

Niewatpliwie jednak kluczowa dla budowy nowej formy rządów była II część małej konstytucji. Istniejący dotąd zespół naczelnych organów państwowych poszerzony został o SU, ale ta zmiana pociagała za sobą przede wszystkim całkowitą rekonfigurację istniejącego systemu. Wynikała ona nie tyle z konieczności uwzględnienia organu przedstawicielskiego, ile zasadniczego przekierunkowania relacji między podmiotami nowej formy rządów i dokonanego przewrotu kompetencyjnego. W świetle II części małej konstytucji użyte zarówno w tytule samej uchwały, jak i jej treści sformułowanie „o powierzeniu Józefowi Piłsudskiemu dalszego sprawowania urzędu Naczelnika Państwa" okazało się nieco mistyfikujące. O ile bowiem urząd nosił formalnie tę samą nazwę, jak przed 20 lutego 1919 r., o tyle jego materialna treść uległa fundamentalnej zmianie. Gdy w dekrecie z 22 listopada 1918 r. obwieszczono, że Naczelnik Państwa objął najwyższą władzę w państwie, to nowa regulacja przesądziła, że odtąd organem tym stał się SU. Dla ukształtowania charakteru ustrojowego organu reprezentacji narodowej posłużono się określeniem: władza suwerenna i ustawodawcza, co wywołało krytyczny komentarz ze względu na niespójność terminologiczną. Jak wskazał W. Komarnicki, użyte w małej konstytucji pojęcie władzy suwerennej

${ }^{35}$ Co więcej, o jakimkolwiek rozliczeniu J. Piłsudskiego z tego tytułu nie wspomniano nie tylko w małej konstytucji, ale jakimkolwiek akcie SU odnoszącym się do okresu sprzed jego zebrania się.

${ }^{36}$ Przepis określający, że dekrety ustanowione przed zebraniem się SU miały być mu przedłożone na 1. posiedzeniu dawał podstawy do dalszych spekulacji na temat potencjalnych czynności, które mogły być wobec nich i ich twórców (Rada Ministrów) podjęte.

37 W. Komarnicki, op. cit., s. 53. 
jako zakresowo najszersze obejmowało także władzę ustawodawczą a tym samym jej wskazanie było zbędne.

Wydaje się jednak, że należy na użyte określenia spojrzeć także z perspektywy jego bezpośrednich twórców. Wyrośli oni w ustrojach, w których pojęcie suwerena było zawarowane dla monarchów, stąd upadek ustrojów monarchicznych był dla nich przejawem zrzucenia jarzma obcej władzy, ale także wyzwoleniem jednoczącego się narodu do sprawowania pełnej, najwyższej i niegraniczonej władzy. Mając świadomość, że suwerenność narodu objawia się na drodze prawnej — jak to pojmowano ówcześnie - jedynie poprzez wybory parlamentarne, wyrażono w uchwale wolę, aby reprezentacja suwerena na czas, gdy ten formalnie „milczy”, została uznana za sprawującą delegowaną jej władzę najwyższą i nieograniczoną. Niewątpliwie dla części posłów sprawowanie jej przejściowo przez J. Piłsudskiego w poprzednim systemie rządów było sygnałem potencjalnego zagrożenia wynikającego z legitymizowania się wolą suwerena przez inny, konkurencyjny względem parlamentu, podmiot ${ }^{38}$. W użytym w małej konstytucji wobec Sejmu pojęciu ,władza suwerenna” nie należy dostrzegać samokreacji nowego podmiotu władzy państwowej, a odwołanie się do kluczowej dla konstytuanty legitymacji sprawowania władzy ${ }^{39}$. Użyte wobec konstytuanty określenie władzy suwerennej nie czyniło z niej suwerena, lecz podkreślało jej charakter jako jedynego organu legitymowanego wolą suwerena - organu bezpośredniego ${ }^{40}$.

Określenie władza suwerenna niosło za sobą także inne treści. Niewątpliwie było wskazaniem, że w stratyfikacji wszystkich organów państwowych SU zajmuje pozycję nadrzędną wobec zarówno Naczelnika Państwa, jak i rządu. Oznaczało to, że odrzucona została po raz kolejny zasada podziału władzy jako klucz do organizacji aparatu państwowego, przy czym gdy uczynił to po raz pierwszy Piłsudski, brakowało realnych podstaw do oparcia się o nią choćby ze względu na brak jakiejkolwiek formy zbiorowego przedstawicielstwa narodu czy kształtowanie się pozostałych władz. Ponownie więc, mimo pojawienia się już realnych możliwości implementacji tej zasady, wybrano ideę koncentracji władzy tym razem w formie rządów zgromadzenia. To zaś w konsekwencji czyniło wtórnym kwestię precyzyjnego określenia roli ustrojowej pozostałych organów państwowych. W istocie bowiem za określeniem konstytuanty władzą suwerenną kryło się prawo swobodnego charakteryzowania misji pozostałych organów, będących adresatami przyszłych zadań państwowych ${ }^{41}$. Inną

38 Problem ten objawił się w następnych miesiącach, gdy projekty przyszłej ustawy zasadniczej, przewidujące powszechny wybór głowy państwa wpłynęły do konstytuanty. A w latach następnych problem suwerenności narodu stał się kluczowym zagadnieniem wynikłym na kanwie dyskusji prowadzonej przed uchwaleniem konstytucji kwietniowej.

39 Podobnie R. Kraczkowski, op. cit., s. 15. Odmiennie S. Krukowski, op. cit., s. 13.

${ }^{40}$ Notabene, o ile zasada suwerenności narodu nie była podważana na początku lat dwudziestych XX w. przez główne siły polityczne (inna rzecz na ile wyrażało to ugruntowane przekonania, a na ile było manewrem taktycznym), o tyle w latach następnych zarówno w Europie, jak i w Polsce podjęto próby jej wyraźnej deprecjacji, czego doskonałym przykładem były prace nad polską konstytucją kwietniową z 1935 r.

${ }^{41}$ Przykładem o znaczeniu fundamentalnym takiego podejścia była kwestia przyszłej ustawy zasadniczej. Początkowo wyrażano pogląd, że podstawą prac nad konstytucją będą projekty poselskie. Jednak już 
konsekwencją przyjęcia formuły zwierzchniej władzy konstytuanty była, jak słusznie zauważył Zbigniew Witkowski, deprecjacja położenia pozostałych organów czyli Naczelnika Państwa i rządu ${ }^{42}$. Objawiała się nie tylko w utracie dotychczasowej pozycji, ale też w nieograniczonej swobodzie konstytuanty do modelowania pozostałych organów. Skoro bowiem wprowadzono zasadę nadrzędności SU w systemie organów państwowych, pozostałe podmioty systemu rządów nie miały po swej stronie żadnych argumentów ustrojowych, mogących chronić je przed hegemonią konstytuanty ${ }^{43}$.

Innym powodem zastosowania pojęcia władzy suwerennej jako formy charakterystyki SU był brak pełnej świadomości głównych sił politycznych co do realnego kształtu kompetencyjnego tego organu. Najbardziej skonkretyzowana została funkcja ustawodawcza jako oczywista i w praktyce politycznej okresu zaborów zapoznana przez wielu posłów do SU, którzy wcześniej zasiadali w parlamentach państw zaborczych. Stąd też jej wyraźne wskazanie, w sposób dostosowany do szczególnej pozycji konstytuanty. Charakterystyczne jest potraktowanie funkcji ustawodawczej jako w całości kompetencyjnie zawłaszczonej przez konstytuantę i nieograniczonej przedmiotowo. Dominacja kompetencyjna wyrażała się w pominięciu milczeniem w małej konstytucji prawa inicjatywy ustawodawczej (nie przypisano jej zarówno Naczelnikowi Państwa, jak i Radzie Ministrów, działającym razem lub osobno), co przy deklarowanej nadrzędności Sejmu mogło sugerować pozbawienie obu organów tego uprawnienia. Dopiero kompetencja ta, definiowana jako prawo Rady Ministrów do składania pisemnych wniosków, została przyjęta w art. 15 tymczasowego regulaminu obrad.

Równie znamienne było pozbawienie Naczelnika Państwa kompetencji do podpisywania przyjętych przez SU ustaw i jej scedowanie na marszałka Sejmu za kontrasygnatą prezydenta Ministrów i właściwego ministra. Za tym symbolicznym podkreśleniem pełni praw Sejmu do kształtowania ustawodawstwa szło pozbawienie wpływu na nie innych organów. Zniknęło prawo sankcji, żaden z pozostałych organów nie uzyskał możliwości zastosowania weta ustawodawczego, choćby w formie zawieszającej, a nawet wpływu na przebieg postępowania ustawodawczego, np. poprzez wniosek o jego przyspieszenie, co w tymczasowym regulaminie było uprawnieniem grupy co najmniej 15 posłów. Nieograniczonemu przedmiotowo zakresowi uchwalanych ustaw towarzyszył wyraźny brak podziału materii podległej prawodawczemu normowaniu przez organy państwa. W ten sposób ustawa stawała się dogodnym regulatorem problematyki zarówno w kwestiach o charakterze generalnym i o wymiernym znaczeniu

12 marca 1919 r. Komisja Konstytucyjna wezwała rząd I.J. Paderewskiego do przedstawienia własnego projektu ustawy zasadniczej, a gdy on okazał się niedostateczny, główne prace rozpoczęły się 1 grudnia 1919 r. po przedstawieniu kolejnego projektu, tym razem przez rząd L. Skulskiego Confer szerzej S. Krukowski, Geneza konstytucji z 17 marca 1921 r., Warszawa 1977.

42 Confer Z. Witkowski, op. cit., s. 20. Podobnie uważał czołowy poseł endecji S. Głąbiński, Wspomnienia polityczne, Pelplin 1939, s. 422 i n.

${ }^{43}$ Dobitnie scharakteryzował powstały ten system rządów poseł S. Głąbiński, ,Polska bowiem nie jest państwem monarchicznym, w którem możliwe są konflikty między reprezentacją narodu a monarchą, ale jest państwem demokratycznym, w którym zarówno rząd jak i Naczelnik Państwa są wykonawcami woli Sejmu Ustawodawczego"; spr. sten. z 324. posiedzenia SU, 5 lipca 1922 r., 1. 19. 
ustrojowym $^{44}$, jak w kwestiach wzbudzających zainteresowanie jedynie pewnych grup posłów, często o wymiarze indywidualnym ${ }^{45}$. Co więcej, ustawa często była traktowana jako instrument zlecania rządowi konkretnych zadañ ${ }^{46}$, podkreślając wyraźnie, że kreatorem polityki państwa stała się konstytuanta.

Inne obszary władczej dominacji SU zostały już określone bardziej ogólnie, co przy braku hamulców ustrojowych lub środków inicjatywnych, leżących po stronie innych organów państwowych, a nade wszystko przy ukształtowaniu konstytuanty jako organu najwyższego, dawało podstawę do traktowania tego rozwiązania jako swoistego domniemania kompetencji na jej rzecz ${ }^{47}$. W małej konstytucji nie wspomniano o konkretnych instrumentach kontroli parlamentarnej wobec Naczelnika Państwa i rządu, choć pewne z nich znalazły się wcześniej w tymczasowym regulaminie obrad, jak choćby interpelacje czy prawo żądania obecności na posiedzeniach komisji. Wszystko to miało ulegać twórczemu rozwinięciu w drodze praktyki, a obok „suwerennego" charakteru władzy konstytuanty, zachęcała do tego szeroko rozciagnięta odpowiedzialność parlamentarna Naczelnika Państwa i rządu. Odpowiedzialność ta nie została bezpośrednio scharakteryzowana w małej konstytucji, co prowadziło W. Komarnickiego do przyjęcia stanowiska, zgodnie z którym obie jej formy (polityczna i prawna) były dopuszczalne ${ }^{48}$. Oponował przeciwko temu S. Krukowski, wskazując, że ze względu na charakter odpowiedzialności prawnej powinny zostać choćby w rudymentarnym zakresie rozstrzygnięte takie zagadnienia jak prawo inicjowania postępowania, forma jego prowadzenia, podmiot rozstrzygający w kwestii odpowiedzialności, nie wspominając o określeniu sankcji nałożonych na osobę uznaną winną naruszenia prawa ${ }^{49}$. O ile

${ }^{44}$ Przykładowo: ustawa z dnia 28 marca 1919 r. o załatwianiu zatargów zbiorowych pomiędzy pracodawcami a pracownikami rolnymi; ustawa z dnia 11 kwietnia 1919 r. o utworzeniu Głównego Urzędu Zaopatrywania Armii; ustawa z dnia 24 lipca 1919 r. o policji państwowej; ustawa z dnia 1 sierpnia 1919 r. o tymczasowej organizacji zarządu b. dzielnicy pruskiej; ustawa z dnia 20 stycznia 1920 r. o obywatelstwie Państwa Polskiego; ustawa z dnia 30 kwietnia 1920 r. o biletach skarbowych.

45 Przykładowo: ustawa z dnia 28 lutego 1919 r. w przedmiocie zaopatrzenia ludności w drzewo budulcowe i opałowe; trzy ustawy z dnia 11 kwietnia 1919 r. o budowie linii kolejowej Łódź-Kutno-Płock, o budowie linii kolejowej Kutno-Strzałków i o budowie linii kolejowej Płock-Sierpc, oraz o przebudowie wąskotorowej linii Nasielsk-Sierpc; ustawa z dnia 29 kwietnia 1919 r. o obwałowaniu lewego brzegu Wisły od ujścia Potoku Kościelnickiego do Zawichostu; ustawa z dnia 18 listopada 1919 o obrocie ziemiopłodami w roku gospodarczym 1919/1920; ustawa z dnia 9 lipca 1920 r. o zasiłku w kwocie 4,5 mln koron dla szkół Głównego Zarządu Towarzystwa Szkoły Ludowej w Krakowie, prowadzonych dla mniejszości polskich w Galicji Wschodniej.

46 Przykładowo w każdej z trzech wspomnianych ustaw „kolejowych” z 11 kwietnia 1919 r. zawarto w art. 1 każdej z nich imperatywny zwrot „Poleca się Ministrowi Kolei przystapić do budowy [...]”. Zasadą było, że każda ustawa w przepisach końcowych zawierała polecenie jej wykonania adresowane szczegółowo zarówno do Rady Ministrów, jak i konkretnych ministrów, a także innych organów państwowych. Innym przykładem zlecania zadań ministrom z pominięciem rządu były uchwały określające ich konkretne zadania ustawodawcze do wykonania, np. na 13. posiedzeniu SU 11 marca 1919 r. podjęto uchwałę następującej treści: „Poleca się Komisji Ochrony Pracy jak najszybsze nawiązanie kontaktu z odnośnym ministerstwem w celu opracowania omówionych ustaw" (mowa o ustawach ubezpieczeniowych dla robotników od kalectwa, bezrobocia i emerytalnych).

${ }^{47}$ Zwracał na to uwagę już w maju 1919 r. M. Rostworowski, Wytyczne konstytucji polskiej, Kraków 1919, s. 6.

${ }^{48}$ W. Komarnicki, op. cit., s. 67. Podobny pogląd wyraził M. Pietrzak, op. cit., s. 50.

${ }^{49}$ S. Krukowski, op. cit., s. 13-14. 
argumenty te jednoznacznie przesądzałyby wspomnianą kwestię w państwie działającym z utrwalonym porządkiem prawnym i wierną legalizmowi klasą polityczna, o tyle w przypadku państwa znajdującego się w fazie stopniowego krzepnięcia, z brakiem reguł odnoszących się do prawotwórstwa i o niewyrobionym poczuciu praworządności u klasy politycznej, zastrzeżenia S. Krukowskiego tracą na znaczeniu. Pozycja SU i związane z tym poczucie jego omnipotencji podzielane przez większość posłów pozwalały zakładać zarówno zlekceważenie zasady lex retro non agit, jak i ukształtowanie pełnej procedury tej odpowiedzialności ad causum. Było to możliwe, ponieważ ponoszenie odpowiedzialności prawnej przed parlamentem nie było abstrakcją w innych ustrojach państwowych, a pozycja zajmowana przez Sejm pozwalała na podjęcie także tej aktywności. Jednak w praktyce politycznej kwestia odpowiedzialności prawnej Naczelnika Państwa i ministrów nie była na tyle istotna, aby podjęto się jej materializacji. Co więcej, gdy podejmowano się egzekwowania odpowiedzialności Naczelnika Państwa i rządu, to zawsze to czyniono w trybie odpowiedzialności politycznej bez próby zainicjowania innej formy odpowiedzialności, być może także ze względu na dużo większą swobodę jej stosowania niż w przypadku odpowiedzialności konstytucyjnej czy prawnej.

Zgodnie z przyjętą w małej konstytucji konstrukcją dualnej odpowiedzialności parlamentarnej, ponosiły ją rząd i Naczelnik Państwa. Zakresy przedmiotowe odpowiedzialności obu organów nie zostały przy tym precyzyjnie określone, ograniczając się do stwierdzenia, że każdy z organów ponosi ją za „sprawowanie swego urzędu”. Wobec jednak mgławicowego określenia zakresu działania Rady Ministrów i tylko nieco wyraźniejszej charakterystyki tego obszaru w odniesieniu do głowy państwa, prowadziło to często do elastycznego interpretowania owej klauzuli przy krytyce obu organów.

Naczelnik Państwa mimo odpowiedzialności parlamentarnej został też zobligowany do uzyskania kontrasygnaty każdego swego aktu państwowego przez właściwego ministra. Teoretycznie oznaczało to, że wszelkie rozstrzygnięcia głowy państwa wymagały akceptacji przedstawiciela rządu, co stwarzało podstawy do hamowania działalności Naczelnika Państwa, szczególnie przy założeniu, że rząd będzie emanacją większości sejmowej, niechętnej lub wręcz wrogiej J. Piłsudskiemu. Ale w sytuacji, gdy uzyskana kontrasygnata nie zwalniała Naczelnika Państwa z odpowiedzialności parlamentarnej, obarczając nią także członka rządu, paradoksalnie głowa państwa czuła się tym wymogiem mniej związana, skoro nadal miała ponosić odpowiedzialność za podjęte przez siebie akty państwowe. System dualnej odpowiedzialności parlamentarnej, choć podkreślał nadrzędne stanowisko SU wobec obu organów, nie mógł przynieść zamierzonego efektu w postaci powstrzymywania Naczelnika Państwa ${ }^{50}$. Skoro mała konstytucja nie wiązała explicite z uzyskaniem kontrasygnaty właściwego ministra dla aktu państwowego Naczelnika przymiotu jego ważności, nadawało to pozycji głowy państwa większą swobodę w kreowaniu tych aktów ${ }^{51}$. Formy egzekwowania odpowiedzialności parlamentarnej Naczelnika Państwa oraz rządu nie zostały w małej konstytucji

${ }^{50}$ Odmiennie M. Pietrzak, op. cit., s. 49 i n. oraz W.T. Kulesza, op. cit., s. 41.

${ }^{51}$ Odmiennie W. Komarnicki, op. cit., s. 67, natomiast podobnie S. Krukowski, op. cit. 
określone, co na tle przyjętych w tym okresie rozwiązań w wielu państwach europejskich, nie było niczym zaskakującym, ale w oczywisty sposób dawało konstytuancie swobodę w wyborze środka wyrażania swego stanowiska w tym obszarze.

Ukształtowanie pozycji Naczelnika Państwa było efektem panujących w konstytuancie relacji międzypartyjnych, dla których jednym z wyznaczników był stosunek do J. Piłsudskiego, ale przede wszystkim wynikało z konieczności jasnego usytuowania Naczelnika Państwa w nowym systemie rządów. Jak bowiem trafnie zauważyła Dorota Malec, forma rządów przyjęta w małej konstytucji była antytezą rządów ustalonych dekretem z 22 października 1918 r., a łącznikiem między nimi był Piłsudski, tyle że jego rola uległa istotnej transpozycji52. Skoro utracił dotychczasową pozycję na rzecz Sejmu, należało znaleźć formułę, która odzwierciedlając położenie ustrojowe konstytuanty plasowała Naczelnika Państwa w sposób niestwarzający ryzyka restytucji poprzedniego jego umiejscowienia. Nowy status Naczelnika Państwa w systemie rządów kreowanym przez małą konstytucję był refleksem i konsekwencją zajęcia jego dotychczasowego miejsca przez konstytuantę ${ }^{53}$.

Z tą myśla, w małej konstytucji określono rolę Naczelnika Państwa w pierwszej kolejności jako „przedstawiciela państwa”, a więc przyznając mu atrybut głowy państwa. W charakterystyce tej zwraca jednak uwagę brak przymiotnika „najwyższy”, który jasno stratyfikowałby Naczelnika Państwa wobec innych potencjalnych podmiotów reprezentacji państwowej. Chociaż przymiotem reprezentanta nie został obdarzony w małej konstytucji żaden inny z organów, to w praktyce - np. w dyplomatycznej, ale też wewnątrzkrajowej - określenie to używane było również na niższych poziomach władzy. Wydaje się, że taka charakterystyka Naczelnika Państwa miała prowadzić do zachowania równowagi, a może nawet do powstrzymywania Naczelnika Państwa w sferze aktywności, w tym także międzynarodowej, poprzez rolę równolegle i faktycznie odgrywaną przez rząd, prezydenta Ministrów i ministrów. W istocie bowiem funkcję reprezentanta państwa konstytuanta pojmowała w dwóch płaszczyznach: czysto symbolicznej (jako forma ucieleśnienia państwa w czynnościach podejmowanych przez Naczelnika Państwa) oraz wyraźnie wtórnej (jako realizująca wolę konstytuanty poprzez konkretne akty działania wynikające bezpośrednio lub pośrednio z dyspozycji SU) ${ }^{54}$. Takiemu odczytaniu reprezentacji w stosunkach wewnętrznych i zewnętrznych sprzyjała pozostała część konstytucyjnej charakterystyki Naczelnika Państwa jako „najwyższego wykonawcy uchwał Sejmu Ustawodawczego w sprawach cywilnych i wojskowych". Zgodnie z nią nie pojawiała się więc żadna wolna przestrzeń, pozwalająca na poszukiwanie zakotwiczenia dla jakiegokolwiek wpływu Naczelnika Państwa na politykę państwa. Tak uszczuplona formuła reprezentacji nie dawała też pola do interpreta-

52 D. Malec, Sejm Ustawodawczy 1919-1922. W 90. rocznice pierwszego posiedzenia, „Przegląd Sejmowy" 2009, nr 1, s. 25.

53 A. Próchnik, Pierwsze piętnastolecie Polski niepodleglej, Warszawa 1983, s. 54 i n.

${ }^{54}$ K.W. Kumaniecki w komentarzu do małej konstytucji uważał, że „Naczelnik Państwa jest przedstawicielem państwa naprawdę właściwie tylko w zakresie reprezentacyjnym, poza tem treści władzy nie posiada." Idem, Odbudowa państwowości polskiej. Najważniejsze dokumenty 1912-styczeń 1924, Warszawa-Kraków 1924, s. 167. 
cji dopuszczającej istnienie jakiejś sfery, w której głowa państwa ma silniejsza, pierwszoplanową możliwość działania nawet o charakterze symbolicznym.

Ta część charakterystyki Naczelnika Państwa jeszcze dobitniej sytuowała jego relacje z SU. W małej konstytucji określając go „najwyższym wykonawcą uchwał Sejmu", położono kres dotychczasowej jego roli jako inicjatora i kreatora polityki państwa oraz podmiotu dysponującego możliwością samodzielnego określania środków i metod jej wdrażania. Tym samym wykonawstwo wpisane w rolę ustrojową Naczelnika Państwa sprowadzono do czystego egzekwowania ustaleń podjętych poza nim przez SU, bez względu na formę ich przyjęcia. Była to więc zasadnicza różnica między pojęciem władzy wykonawczej w układzie wyznaczonym przez zasadę podziału władzy, z wyraźnie zaznaczoną odrębnością organizacyjna, zadaniową i funkcjonalna, a wykonawstwem rozumianym jako techniczne wdrażanie dyrektyw kształtowanych przez Sejm, w układzie jego nadrzędności i warunkach braku autonomii decyzyjnej organów wykonawczych. Zwraca uwagę szerokie ujęcie formy prawnej dyspozycji wydawanych Naczelnikowi Państwa. Uchwały, o których mowa we wspomnianym postanowieniu małej konstytucji, to jedynie naturalna formuła wypowiadania się organu kolegialnego. Obejmowała ona wszelkie stosowane przez konstytuantę akty o charakterze dyrektywnym, które mogły być skierowane do pozostałych organów państwowych, w tym — rzecz jasna - Naczelnika Państwa. W praktyce akty te - o różnej formie prawnej i podejmowane nie tylko przez izbę in pleno, ale też jej organy - kierowano z reguły do rządu ${ }^{55}$.

Choć przymiotnik ,tymczasowy” zniknął z nazwy urzędu piastowanego przez J. Piłsudskiego, to jednak przejściowy charakter rozwiązań prawnych odnoszących się do głowy państwa uległ podtrzymaniu w świetle postanowień małej konstytucji. Jednoznacznie na zamiar szybkiej zmiany stanu prawnego wskazują postanowienia konstytucyjne wyznaczające czas ich obowiązywania ,[...] do ustawowego uchwalenia tej treści Konstytucji, która określi zasadniczo przepisy o organizacji Państwa”. Łatwo dostrzec, że w tej dyspozycji mieściła się przyszła ustawa zasadnicza, ale także ewentualność uchwalenia odrębnej ustawy, regulującej jedynie fragmentarycznie wskazany wcześniej wycinek pełnej konstytucji. Dalsza prowizoryczność regulacji odnoszącej się do Naczelnika Państwa wytwarzała wrażenie niestabilności jego pozycji, co widoczne było na tle braku postanowień wyznaczających czasowy horyzont działania $\mathrm{SU}^{56}$. Brakowało zarówno norm pozwalających ustalić kadencję konstytuanty,

${ }_{55} \mathrm{~Np}$. na posiedzeniu 11 marca 1919 r. skierowane do rządu wezwanie w sprawie odbudowy mostu na Sanie w Przemyślu, a 14 marca 1919 r. wezwanie, aby „,...] rząd w ciągu 15 dni przedstawił Komisji Administracyjnej szczegółowy schemat organizacji poszczególnych ministerstw, jak również wykazy poszczególnych urzędników, przepisów wykonawczych, regulaminów itd. w celu ich uzgodnienia i wprowadzenia potrzebnych zmian, a przede wszystkim śpiesznego i należytego rozgraniczenia kompetencji Ministerstw". Zapewne było to spowodowane względami praktycznymi (wszak rząd dysponował aparatem administracyjnym), ale też politycznymi, gdyż w praktyce politycznej było jasne, że to rząd, a nie Naczelnik Państwa jest ściśle uzależniony od Sejmu.

${ }^{56}$ Po części mogło wynikać z powiązania czasu pracy konstytuanty z naczelnym zadaniem, czyli przyjęciem nowej ustawy zasadniczej. W praktyce jednak okazało się, że dopełnienie tego obowiązku nie zdeterminowało końca działalności SU, który funkcjonował jeszcze blisko dwa lata. 
ale także instrumentów leżących poza parlamentem, pozwalających organom wykonawczym oddziaływać na okres pracy SU; nie dysponowały one możliwością rozwiązania parlamentu, a z racji przyjęcia przez konstytuantę systemu permanencji obrad, nie mogły tym samym wpływać na sesję parlamentarną i terminy zwoływania posiedzeń konstytuanty. Tym samym na tle SU z normatywnego punktu widzenia Naczelnik Państwa rysował się jako organ o dużym ryzyku nietrwałości, ale w równym stopniu wpływało to na pozycję Piłsudskiego jako dzierżyciela tego urzędu. Wszak wraz z kolejnym zapowiadanym w małej konstytucji posadowieniem ustrojowym głowy państwa, zaszłaby potrzeba jej obsadzenia, tak jak stało się to w wyniku przyjęcia małej konstytucji. Jak się wydaje, wkomponowanie z góry w urząd Naczelnika Państwa niestabilności nie było przypadkowe. W głowach znacznej części posłów tliło się — stale podsycane — przekonanie, że Piłsudski może stanowić wyraźne zagrożenie dla dominacji SU, stąd wprowadzenie elementów podważających definitywność rozwiązań ustrojowych odnoszących się do głowy państwa miało pozbawić atrakcyjności politycznej próby budowania wokół niego przeciwwagi dla konstytuanty.

Domknięciem formy rządów wytworzonej w małej konstytucji były niezwykle skromne postanowienia odnoszące się do rządu, wyrażające ducha rządów komitetowych. Rząd został pozbawiony osłony normatywnej dla swej koniecznej — choćby minimalnej - autonomii kompetencyjnej, funkcjonalnej i organizacyjnej. Pominięto charakterystykę roli ustrojowej pełnionej przez Radę Ministrów, co mogło prowadzić do wniosku, że Naczelnik Państwa jako najwyższy wykonawca wspierany przez rząd będzie tworzyć zespół wykonawców woli SU. Taki związek funkcjonalny nie został jednak uwzględniony w prowizorycznej konstytucji, wręcz założono daleko idącą odrębność obu organów. Istniejące regulacje wiązały rząd dużo ściślej z SU niż Naczelnikiem Państwa, wyraźnie likwidując układ wytworzony między głową państwa i rządem przed wejściem w życie małej konstytucji. Po pierwsze, już u swej genezy każdy formujący się gabinet musiał być wyrazem porozumienia między Naczelnikiem Państwa a SU. Porozumienie to dotyczyło pełnego składu rządu, co miało dobitnie wskazywać, że nie uczyniono wyjątku dla żadnego z ministrów (obawiano się bowiem autonomizacji ministra spraw wojskowych), który mógłby być powoływany z pominięciem SU. Po drugie, odpowiedzialnością parlamentarną objęto zarówno cały rząd (odpowiedzialność solidarna), jak i poszczególnych jego członków (odpowiedzialność indywidualna). Tym samym znana z poprzednio obowiązującego systemu rządów odpowiedzialność przed Naczelnikiem Państwa przeszła do historii. Przy braku jakiegokolwiek mechanizmu osłonowego, który mógłby być wsparciem ze strony głowy państwa udzielonym rządowi w przypadku zagrożenia pociagnięciem do odpowiedzialności parlamentarnej, a nadto uwzględniając, że głowa państwa także ponosiła ją przed konstytuanta, relacje głowy państwa z rządem zastapiono ścisłym związkiem rządu z konstytuantą. Głowa państwa nie miała bowiem instrumentu budującego jej wpływ na rząd, nie mówiąc o możliwości tworzenia równowagi między parlamentem a pozostałymi organami wykonawczymi. O ile zdolność konstytuanty do pociagnięcia do odpowiedzialności politycznej Naczelnika Państwa była raczej umiarkowana, choć- 
by ze względu na jego osobisty autorytet, ale też wierność polityczną części posłów, o tyle w przypadku rządu w praktyce nie występowały w SU zahamowania przed silnym, dyspozycyjnym oddziaływaniem na rząd, włącznie z gotowością do wymuszenia ustapienia rządu i jego poszczególnych członków.

Organizacji Rady Ministrów czy jej relacjom z pozostałymi organami państwowymi, w tym administracją nie poświęcono w małej konstytucji miejsca. Pominięto rolę prezydenta Rady Ministrów, co dobrze wpisywało się w trend osłabiania wszelkich jednoosobowych form działalności państwowej. Jego pominięcie kompetencyjne, przy jednoczesnym wskazaniu jako organu kontrasygnującego akty ogłaszane przez marszałka Sejmu dawało jednak podstawę do wskazania, że — z jednej strony — stoi on na czele rządu (a w takim przypadku kierowanie rządem bezpośrednio przez Naczelnika Państwa nie jest możliwe $)^{57}$, z drugiej zaś - to rząd z prezydentem na czele jest faktycznym ,technicznym” wykonawcą woli SU.

System rządów określony w małej konstytucji był poddany wielokrotnie analizie. W jego ocenie powtarza się często pogląd, że w ten sposób w Polsce został zaprowadzony system parlamentarny w skrajnej postaci ${ }^{58}$. Wydaje się jednak, że opinia ta opiera się nie tyle na ocenie normatywnej, co uwzględnia praktykę ustrojową tego okresu, która złagodziła cechy projektowanego w małej konstytucji systemu bliskiego rządom zgromadzenia czy też rządom komitetowym ${ }^{59}$. Analiza nadanych mu cech prowadzi do wniosku, że czynniki określające pozycję samego parlamentu (jedyny organ o charakterze pierwotnym, a jednocześnie organ najwyższy, określający politykę państwa, brak jakichkolwiek ograniczeń w materialnym i proceduralnym kształtowaniu własnych rozstrzygnięć, w tym ustawodawstwa, a nawet norm konstytucyjnych, domniemanie kompetencji na rzecz parlamentu i system permanencji jego obrad, nieograniczona kontrola nad organami wykonawczymi), jak i relacje konstytuanty z organami wykonawczymi (całkowite uzależnienie powoływania organów wykonawczych od konstytuanty i ich nieograniczona podległość konstytuancie, obowiązek realizowania zadań określonych przez Sejm, brak konstytucyjnie określonego zakresu właściwości, zadań i kompetencji) oddalały — przynajmniej w założeniu — z grubsza zarysowaną w małej konstytucji formę rządu od rozwiązań właściwych systemowi parlamentarnemu.

\section{SYSTEM RZĄDÓW PRAKTYKOWANY W OKRESIE OBOWIĄZYWANIA MALEJ KONSTYTUCJI}

Jeżeli jednak uznaje się okres obowiązywania małej konstytucji za wprowadzenie do systemu parlamentarnego, formalnie istniejącego od wejścia w życie konstytucji marcowej, to przede wszystkim ze względu na fakt, że założenia systemu rządów zgromadzenia okazały się nierealne. Utrzymanie tego założenia stało się niemożliwe głównie ze względu na stan systemu partyjnego, który miał charakter nieskonsolidowany,

${ }^{57}$ Co zresztą odzwierciedlało występujący stan rzeczy zarówno pod rządami dekretu z 22 listopada 1918 r., jak i po przyjęciu małej konstytucji.

${ }^{58}$ Confer M. Pietrzak, op. cit., s. 50, S. Krukowski, op. cit., s. 13.

${ }^{59}$ Confer W. Komarnicki, op. cit., s. 73 i n. 
charakteryzujący się dużą i stale postępującą fragmentaryzacją stronnictw parlamentarnych wynikającą z różnorodności programowej, ale też silnych podziałów socjopolitycznych i porozbiorowych wzmagających antagonizmy międzypartyjne i wewnątrzpartyjne. Partie - z reguły o słabym poziomie instytucjonalizacji, szczególnie $\mathrm{w}$ wymiarze pozaparlamentarnym, z niską dyscypliną organizacyjna, z silnie zaznaczającymi ruchami odśrodkowymi, często motywowanymi osobistymi animozjami i ambicjami - nie były w stanie wytworzyć stałych, przewidywalnych reguł współistnienia w systemie partyjnym, co również znajdowało swoje odzwierciedlenie w niezwykle rzadkim i krótkotrwałym funkcjonowaniu koalicji parlamentarnych i rządowych ${ }^{60}$. Zasadniczym fundamentem ich tworzenia było zaspokojenie ambicji uczestnictwa w rządzie najbardziej wpływowych w danym momencie członków poszczególnych ugrupowań parlamentarnych ${ }^{61}$. Przykładowo, w trakcie debaty nad exposé premiera W. Witosa, poseł I. Daszyński podniósł pod adresem jednego z posłów: „Pan Głąbiński, z przeproszeniem, rozpęd bierze ku ławie ministerialnej jeszcze od lata 1920 r. kiedy przyszedł w imieniu swego klubu siebie na ministra finansów zaproponować i kiedy odszedł z tem gorzkiem przekonaniem, że jego przyjaciel p. Grabski zostanie ministrem finansów, co mu też odpłacono w najbliższej przyszłości" ${ }^{62}$. Podstawy programowe koalicyjnych większości parlamentarnych i rządowych były z reguły ogólne, niekiedy o krótkim horyzoncie czasowym, rzadko z trwalszą wizją rozwiązywania głównych problemów społecznych czy gospodarczych państwa ${ }^{63}$, niekiedy budowane i utrzymywane w celu niedopuszczenia do władzy innych stronnictw.

Od zebrania się SU rzeczą oczywistą było, że stanowi on patchwork ugrupowań politycznych, podlegających stałemu rozdrobnieniu ${ }^{64}$. Kondycja partii i systemu par-

${ }^{60}$ Confer R. Kraczkowski, op. cit., s. 21, M. Pietrzak, Rzady parlamentarne w Polsce w latach 1919-1926, Warszawa 1969, s. 142 i n.

${ }^{61}$ Obrazowo przedstawił to W. Witos, Moje wspomnienia, t. II, Paryż 1964, s. 264 i n.

62 Spr. sten. z 248. posiedzenia SU, 30 września 1921 r., 1. 38.

${ }^{63}$ Przykładowo, wystapienie programowe I.J. Paderewskiego, przedstawione w formie sprawozdania z dotychczasowej pracy oraz planów na przyszłość, było w istocie wezwaniem do kontynuacji dotychczasowych działań, pełnym patetycznych odniesień o charakterze historiozoficznym, lecz poza kwestiami związanymi z konferencją pokojową nie zawierało istotnych konkretów; spr. sten. z 3. posiedzenia SU, 20 lutego 1919 r., 1. 59 i n. Z kolei wystapienie programowe W. Grabskiego, choć następowało w dramatycznym momencie ofensywy rosyjskiej i temu głównie było poświęcone, zawierało stwierdzenie, że 70 projektów ustaw, które zastał po rządzie L. Skulskiego jest już pewną częścią programu jego gabinetu; spr. sten. z 156. posiedzenia SU, 30 czerwca 1920 r., ł. 8. Z kolei exposé W. Witosa składane w sytuacji tworzenia rządu obrony narodowej skupiało się obronie państwa i zawarciu pokoju. Ponowne exposé z 24 września 1920 r. obok podkreślenia dotychczasowych dokonań gabinetu zawierało ogólnie zarysowane cele programowe: reforma rolna, poprawa aprowizacji, odbudowanie zniszczeń po najeździe rosyjskim, likwidacja odrębności dzielnicowych i budowa sprawnego aparatu administracyjnego; spr. sten. z 167. posiedzenia SU, 24 września 1920 r., 1. 11-20. Natomiast A. Ponikowski prezentując program swojego gabinetu wyraźnie zastrzegł, że choć gabinet jego ma charakter pozaparlamentarny i złoży dymisję z chwilą wytworzenia się warunków dla działalności rządu parlamentarnego, to jego intencją nie jest, ,[...] aby zadania i program swego gabinetu dostosował na czas krótki i ograniczony”, spr. sten. z 247. posiedzenia SU, 27 września 1921 r., ł. 6.

${ }^{64}$ Przykładowo, już w 1919 r. w SU ukonstytuowało się 10 klubów, z których największy (Związek Sejmowy Ludowo-Narodowy) liczył 109 posłów na 335 ogółem. W roku 1920 liczba klubów wzrosła do 15, a na koniec kadencji, w 1922 było ich 19. Od 1920 r. żaden z klubów nie zrzeszał więcej niż 100 posłów, dominowały natomiast kluby liczące od 10 do 91 posłów, dane za: A. Ajnenkiel, Historia..., s. 285-287. 
tyjnego czyniła je trudnym budulcem do tworzenia większości, nieodzownej do sformowania koalicji parlamentarnych i rządowych. W istocie poza efektownym początkiem prac SU, gdzie przez aklamację przyjęto kolejno tymczasowy regulamin obrad oraz małą konstytucję, chcąc zamanifestować jedność polityczną, w konstytuancie z reguły dominowały działania dezintegracyjne. Wyjątkowo, gdy sytuacja była krytyczna dla państwa, latem 1920 r. z powodu wojny z Rosją Radziecką udało się przy szerokim konsensie uchwalić np. ustawę o Radzie Obrony Państwa ${ }^{65}$.

Wewnętrzny potencjał konstytuanty — na który obok słabości partii politycznych wpływał też poziom poszczególnych posłów, z których tylko niewielu miało obycie parlamentarne w legislatywach państw zaborczych oraz wyrobienie w aktywności publicznej — musiał także ujawnić się w jej niezdolności do wykonywania swych funkcji. Tymczasem szeroko zakrojone ambicje — aby stać się centralnym ośrodkiem dyspozycji politycznej, co odzwierciedlałoby zawarty w małej konstytucji model rządów zgromadzenia - wymagały jednak spełnienia licznych warunków.

W pierwszej kolejności była to zdolność do konsolidacji politycznej, pozwalającej uformować większość o spójnym programie politycznym, zawierającym określenie celów i zadań powierzonych do realizacji przez organy wykonawcze. Tymczasem przypadki, w których udało się osiagnąć szerszą współpracę, miały z reguły charakter jednostkowy lub krótkotrwały ${ }^{66}$. W kadencji SU utworzono jedynie dwa rządy oparte na większościowej koalicji parlamentarnej — Leopolda Skulskiego i Wincentego Witosa. W obu jednak przypadkach, w trakcie ich funkcjonowania, większość parlamentarną i rządową opuszczali stopniowo poszczególni parlamentarzyści i kluby, a w ślad za tym i członkowie rządu ${ }^{67}$. W znaczącym stopniu implikowało to pogorszeniem się pozycji politycznej rządu, spadkiem efektywności prac Sejmu i rządu, koncentrowaniem się gabinetu na obronie przed wzmagającą się krytyką parlamentarną i upadkiem. Istniejące podziały nie tylko uniemożliwiały stworzenie spójnego programu działania

${ }^{65}$ Ustawa o utworzeniu Rady Obrony Państwa, Dz.U. z 1920 r. nr 53, poz. 327.

${ }^{66} \mathrm{~W}$ trakcie debaty nad exposé A. Ponikowskiego 1 października 1921 r. poseł J. Woźnicki zauważył retrospektywnie m.in.: „Już wówczas, kiedyśmy tu w tym Sejmie uchwalili reformę rolną, pokazało się Sejm ten w najważniejszych zagadnieniach nie ma większości. Ile razy chodziło o wyłonienie rządu, to Sejm był w położeniu zupełnie bezradnem. [...] Sejm ten jest nie tylko niezdolny do rządzenia, ale ma skład taki, że obali każdego, kto przyjdzie do niego z jakimkolwiek śmielszym programem, z jakimikolwiek śmielszymi zamiarami”; spr. sten. z 249. posiedzenia SU z 1 października 1921 r., 1.4 i 6. Z innych pozycji, ale z podobnymi wnioskami wystapił też poseł S. Głąbińskiego, spr. sten. z 248. posiedzenia SU, 30 września 1921 r., 1. 20-21.

${ }^{67}$ Pozycja gabinetu L. Skulskiego zaczęła słabnąć zaledwie po niecałych pięciu miesiącach od jego uformowania w grudniu 1919 r., a ostateczny upadek nastapił po upływie blisko sześciu miesięcy działalności, w wyniku ustapienia najsilniejszej partii koalicyjnej PSL, Piast”. W przypadku rządu W. Witosa już po niecałym półroczu jego działalności z poparcia dla rządu wycofały się endecja, chadecja, PPS i PSL Wyzwolenie, zaś rok 1921 do ostatecznego ustąpienia gabinetu we wrześniu przebiegał głównie pod znakiem nieustających prób budowania poparcia dla rządu, m.in. poprzez sięganie do takich metod jak unikanie głosowania przez posłów partii opozycyjnych; confer szerzej A. Wątor, Gabinet Leopolda Skulskiego; tegoż, Gabinet Wincentego Witosa, [w:] Gabinety Drugiej Rzeczypospolitej, red. J. Pajewski, Szczecin-Poznań 1991, s. 58 i n. oraz s. 76 i n.; A. Próchnik, op. cit., s. 72 i n. oraz 96 i n.; J. Goclon, Rzad Leopolda Skulskiego (13 XII 1919 r.-9 VI 1920 r.) skład, funkcjonowanie i jego polityka wschodnia, ,Acta Universitatis Lodziensis. Folia Historica” 2012, nr 88, s. 196. 
SU i jego organów, ale też wykonania zasadniczego obowiązku organu kierowniczego, jakim było kreowanie polityki państwa. W tym stanie rzeczy dokonywało się to tylko odcinkowo, np. w kwestiach polityki zagranicznej czy reformy rolnej i to w drodze tarć i kompromisów między poszczególnymi ugrupowaniami konstytuanty a rządem, a w pierwszym przypadku z dużym i pierwszoplanowym udziałem Naczelnika Państwa. Na tę sytuację zwracał uwagę minister Stanisław Wojciechowski w swoim wystapieniu sejmowym 1 października 1919 r., mówiąc m.in.: „Niejeden przedstawia je sobie tak, że zbiera się zgromadzenie, radzi nad sprawą i powiada: Ma być tak a tak, a ten organ powinien to wykonać. [...] Skoro mam postępować w ten sposób: «powiedzcie mi czego chcecie, a wszystko czego chcecie, zrobię», [...] staję się ślepym narzędziem tego, co przypadek w tem zgromadzeniu przyniesie, w tem zgromadzeniu, które zresztą kieruje się, nie patrząc w przyszłość, nie rozwagą, nie rozumem, ale nastrojem chwili”" ${ }^{6}$. To zaś prowadziło go do wniosku: „rząd musi wziąć w swoje ręce kierownictwo polityczne, a to jest możliwe tylko przy poparciu Sejmu".

Brak konsolidacji SU choćby w kwestii programu legislacyjnego, wyraźnie wpływał na doraźność i wybiorczość wysiłków ustawodawczych. W trakcie jednej z debat nad przyspieszeniem prac konstytucyjnych w Sejmie w dniu 7 maja 1920 r. poseł Eustachy Rudziński tak scharakteryzował działalność Sejmu w tym zakresie: „Sejm pogrążył się w pracy, powiedziałbym mrówczej, nad opracowaniem całego mnóstwa, całej powodzi wniosków nagłych i nienagłych [chodzi o inicjatywy ustawodawcze — uwaga A.K.], Sejm zaczął tworzyć większe i mniejsze ustawy, mniejszej i większej wagi dla których stworzenia i opracowania przyniosło hasła i pobudki życie, które taranem niejako uderzyło w ten Sejm i zapanowało nad Sejmem. Nie widzimy zaś w pracach Wysokiego Sejmu jakiejś pewnej planowości, która by zapanowała nad tym chaotycznym biegiem wypadków. Życie uderza taranem, życie pewne konieczności i te konieczności doraźnie Wysoka Izba załatwia.[...] Wszystkie te ustawy, albo prawie wszystkie noszą na sobie piętno dorywczości, mają charakter tymczasowości. [...] widzi się pewne istotne niezharmonizowanie tych praw" ${ }^{\prime 9}$.

Przy założeniu kierowniczej roli Sejmu w systemie organów państwowych konieczne było wyraźne rozgraniczenie funkcji konstytuanty od funkcji organów wykonawczych. Tymczasem w praktyce działania SU nigdy nie doszło do ustalenia linii demarkacyjnej rozdzielającej zakresy aktywności konstytuanty i organów wykonawczych, a wręcz często się one krzyżowały ${ }^{70}$. Przywództwo legislacyjne SU szybko okazało się pozorne. Co prawda formalnie monopol ustawodawczy należał do konstytuanty, jednak w praktyce zasadnicze projekty ustaw przygotowywał rząd, choć nieraz nie z własnej inicjatywy, lecz na żądanie Sejmu, wyrażane w licznych rezolucjach, często

68 Spr. sten. z 85. posiedzenia SU, 1 października 1919 r., 1. 20-21.

69 Spr. sten. z 145. posiedzenia SU, 7 maja 1920 r., 1. 35-36.

${ }^{70}$ Niekiedy posłowie wprost przyznawali, że poprzez swe akty SU wkracza w sferę działania organów wykonawczych, np. poseł R. Wasilewski, referując jeden z projektów rezolucji skierowanych do ministra aprowizacji, stwierdzał, że wkracza ona w tę sferę bardzo głęboko, lecz uzasadniał to nieuwzględnianiem przez tego ministra w swej pracy słusznych żądań stowarzyszeń skupionych przy kółkach rolniczych; spr. sten. z 149. posiedzenia SU, 19 maja 1920 r., ł. 23. 
bardzo szczegółowych ${ }^{71}$. Inna rzecz, że posłowie dbali o to, by projekt był traktowany jedynie jako punkt wyjścia do prac parlamentarnych, których ostateczny kształt zależał wyłącznie od woli powstałej w tej kwestii większości posłów. Natomiast rząd nie dysponował instrumentami równoważącymi wpływ posłów na kształt ustawy, poza słownymi próbami perswazji. Często też członkowie rządu w trakcie prac ustawodawczych w komisji sejmowej, ale i na posiedzeniach Sejmu nie zabierali głosu, biernie obserwując bieg wydarzeń ${ }^{72}$.

Ogólna liczba uchwalonych przez SU ustaw wyniosła co prawda 571, ale wśród istotnych regulacji o charakterze generalnym i koncentrujących się na ważnych społecznie i politycznie zagadnieniach, jak choćby dotyczących organizacji administracji, sądownictwa, Prokuratorii Generalnej, szkolnictwa, kontroli państwowej, czasie pracy i urlopach w przemyśle i handlu czy obligatoryjnych ubezpieczeniach na wypadek choroby, znajdowały się regulacje o zakresie wybitnie indywidualnym, interwencyjnym, podyktowane interesem partykularnym, jak np. ustawa o przebudowie węzła kolejowego warszawskiego czy ustawa o przyznawaniu nagród za pomoc w zwalczaniu przemytnictwa. Ustawy tworzone w warunkach targów międzypartyjnych, głównie w komisjach sejmowych, miały z reguły charakter połowiczny, aby zadowolić oczekiwania różnych interesariuszy projektu. W efekcie powstały kompromisowy akt miał często charakter blankietowy, był pełen luk i niejasności terminologicznych, co prowadziło do konieczności konkretyzacji ustawy w drodze aktów wykonawczych, nie zawsze zgodnych z intencją ustawodawcy ${ }^{73}$. Jednak niezdolność Sejmu do regulacji niektórych obszarów prowadziła do wyposażania gabinetu w prawo stanowienia aktów o mocy ustawy ${ }^{74}$. Często też wraz z przyjęciem ustawy równolegle uchwalano rezolucje, które były wytycznymi działania administracji w zakresie wykonywania takiej ustawy ${ }^{75}$. Niekiedy wręcz rezolucje uchwalano w trakcie debat nad preliminarzem budżetowym, instruując rząd lub właściwego ministra nie tylko w kwestii polityki wydatkowej, ale i organizacji pracy resortu ${ }^{76}$.

Szczególnie dojmującą cechą działalności ustawodawczej i uchwałodawczej było nieliczenie się ze skutkami finansowymi podejmowanych inicjatyw i rozstrzygnięć. Jak

${ }^{71}$ Przykładowo: rezolucja z 20 listopada 1919 r. wzywała rząd, ,[...] aby jak najrychlej przedłożył Sejmowi ustawę o dniach świątecznych, która by zmniejszyła ich liczbę do liczby, przyjętej w najbardziej uprzemysłowionych krajach zachodniej Europy, po porozumieniu się ze zwierzchnością duchowną".

72 Confer M. Pietrzak, Rzady parlamentarne w Polsce w latach 1919-1926, Warszawa 1969, s. 240 i n., Z. Wasik, Pozycja komisji parlamentarnych pod rzadami Konstytucji marcowej, Toruń 1981, s. 51.

${ }^{73}$ Confer M. Bobrzyński, op. cit., s. 103 zauważał: „Ustawy pisane tak, że decyzję w najważniejszych dla jednostek sprawach pozostawiały swobodnemu uznaniu urzędnika, otwierały drogę protekcji i korupcji".

${ }^{74}$ Np. ustawa z dnia 2 sierpnia 1919 r. o upoważnieniu Rządu do wydania rozporządzenia, normującego przenoszenie własności nieruchomości ziemskiej.

${ }^{75}$ Np. ustawa z dnia 27 listopada 1919 r. o obowiązku zarządów gmin miejskich dostarczenia pomieszczeń (Dz.U. z 1919 r. nr 92, poz. 498) towarzyszyły trzy rezolucje, w tym m.in. jedna z nich wzywała rząd, „aby ustawę stosował w najoględniejszy sposób i tylko w koniecznej potrzebie”.

${ }^{76} \mathrm{~Np}$. w trakcie debaty nad wykonaniem preliminarza wydatków za okres 1 stycznia-30 czerwca 1919 r., odbytym na początku 1920 r. w części wykonywanej przez Ministerstwo Wyznań Religijnych i Oświecenia Publicznego przyjęto dziewięć rezolucji, a w odniesieniu do Ministerstwu Zdrowia Publicznego - osiem rezolucji. 
trafnie wskazał Michał Pietrzak ${ }^{77}$, SU koncentrował się wyłącznie na wydatkach, czyniąc to zresztą rozrzutnie, zobowiązując wielokrotnie różnych członków rządu do ponoszenia wydatków na cele wskazane przez konstytuantę ${ }^{78}$. Sejm nie określał polityki budżetowej, a rząd nie był w stanie zarówno z przyczyn obiektywnych (stan państwa w organizacji oraz prowadzona wojna nie pozwalały na rzetelne oszacowanie dochodów i wydatków państwa, szczególnie przy zwiększającej się inflacji), jak i subiektywnych (brak koordynacji polityki budżetowej przez szefa rządu, Radę Ministrów lub ministra skarbu, stała skłonność Sejmu do swobodnego decydowania o wydatkach itp.) kreować ani tym bardziej nadzorować wykonywania polityki budżetowej. Dopiero pod koniec 1921 r., po wysłuchaniu wystapienia ministra skarbu Jerzego Michalskiego, przyjęto jednomyślnie rezolucję, zgodnie z którą postanowiono, że Komisja Skarbowo-Finansowa każdy wniosek i projekt ustawy jej przekazany będzie badać pod kątem wydatków z nich wynikających i zbilansowania środkami na ich realizację ${ }^{79}$.

Zmieniające się większości parlamentarne coraz bardziej koncentrujące się na indywidualnych zagadnieniach dzielących poszczególne kluby, np. stosunek do reformy rolnej czy innych działań w tym zakresie jak kontrola państwa nad rynkiem rolnym i polityka sekwestru, warunki życia ludności wiejskiej, czy też takie zagadnienia konstytucyjne jak powołanie drugiej izby, kompetencje i tryb wyboru prezydenta RP sprawiały, że SU nie był w stanie wypracować jednolitego podejścia do systematycznego kontrolowania stanu realizacji wytyczonych celów i powierzonych zadań. W praktyce parlamentarnej kontrola miała charakter przypadkowy i niesystematyczny. Zapewne w pewnym stopniu miał rację minister skarbu Steczkowski, że brak budżetu uniemożliwiał też — przynajmniej częściowo — „,...] wykonywanie konstytucyjnego zarówno prawa jak i obowiązku kontroli władzy wykonawczej, kontroli bez której odpowiedzialność rządu stałaby się fikcją, a czynność prawodawcza Wysokiej Izby w sprawach pociagających za sobą wydatki państwowe, funkcją bezprogramowa, na łaskę przypadku zdaną"80.

Sejm Ustawodawczy mimo niemal codziennych posiedzeń nie był w stanie zaproponować racjonalnego mechanizmu kontroli sprawowanego przez całą izbę. Dominowały działania pobieżne, często inspirowane potrzebą chwili, równie gwałtownie wybuchające, co zamierające. To w efekcie prowadziło do przejęcia działań kontrolnych przez komisje sejmowe. Działania te łączyły się nierozerwalnie z ciagłą ingerencją w zakres działania organów rządowych, przede wszystkim ministrów, często sprowadzając się do wymuszania konkretnych czynności pod groźbą odmowy zaufania dla indagowanych funkcjonariuszy ${ }^{81}$. Najlepszym wyrazem siły komisji sejmowej było

77 M. Pietrzak, Parlament w systemie organów..., s. 63.

${ }^{78} \mathrm{~Np}$. na 67. posiedzeniu SU 10 lipca 1919 r. podjęto rezolucję wzywającą rząd do podjęcia budowy rurociagów, m.in. na rachunek skarbu.

79 Spr. sten. z 250. posiedzenia SU, 4 października 1921 r., ł. 33-35.

${ }^{80}$ Spr. sten. z 243. posiedzenia SU, 28 lipca 1921 r., 1. 9. Podobną refleksję miał poseł S. Rottermund w trakcie wystapienia na 123. posiedzeniu Sejmu, stwierdzając, że „Sejm nie może korzystać z zasadniczego swego prawa konstytucyjnego: kontroli nad wydatkami”; confer spr. sten. ze 123. posiedzenia SU, 24 lutego 1920 r., 1. 4-5.

${ }^{81} \mathrm{~W}$ trakcie debaty nad exposé premiera W. Witosa, poseł A. de Rosset odniósł się do praktyki komisyjnej: „Komisje, które częstokroć przekraczają granice kompetencji sejmowych i wkraczają w dziedzinę 
przybycie na posiedzenie Komisji Skarbowo-Budżetowej premiera W. Witosa, który na jej posiedzeniu bronił zarówno preliminarza budżetowego, jak i jej autora, ministra skarbu Jana K. Steczkowskiego - rozważano wotum nieufności dla niego. Z kolei Komisja Spraw Zagranicznych, wielokrotnie odpytując premierów i ministrów spraw zagranicznych, była czynnikiem współkształtującym politykę zagraniczną, z silną tendencją do kurateli nad ministrem, doprowadzając do dymisji jednego z nich ${ }^{82}$. Szeroko rozwinięta została działalność komisji specjalnych, odpowiednika późniejszych komisji śledczych, których SU powołał ok. 20, często w sprawach o charakterze szczegółowym (np. na skutek zajść w poszczególnych miejscowościach), ale także w sprawach o doniosłym charakterze, np. w sprawie stanu administracji publicznej na Kresach Wschodnich. Warto zauważyć, że zakres ich kompetencji, każdorazowo ustalany, był z reguły szeroki, korespondujący z pozycją $\mathrm{SU}^{83}$.

Realizację funkcji kontrolnej przez SU osłabiał brak systematyczności oraz stabilnych reguł i kryteriów określających postępowania wewnątrzparlamentarne zmierzające do weryfikacji aktywności rządu i ministrów w zakresie wykonywania woli parlamentu. Sprzyjał temu zarówno brak trwałej większości parlamentarnej, potrafiącej w sposób względnie stabilny i przewidywalny określić oczekiwania wobec rządu w dłuższym horyzoncie czasowym, ale też ciagła zmienność gabinetów i jeszcze częstsze zmiany na stanowiskach ministerialnych ${ }^{84}$.

Systemowa wada SU polegająca na chronicznym braku stabilnej większości parlamentarnej w naturalny sposób oddziaływała na relacje z organami wykonawczymi w sferze odpowiedzialności politycznej. Relacje z rządem i Naczelnikiem Państwa uległy wypaczeniu ${ }^{85}$. W odniesieniu do głowy państwa, jego autorytet społeczny, łącze-

bezpośredniego rządzenia, nie tylko sprawom nie dopomagaja, ale sprawy utrudniaja, sprawy prowadzą do zadrażnień, które nie prowadzą do żadnego celu. Przeciążenie naszych komisji sprawami do nich nie należącymi, wcale nie przyczynia się do utrwalenia silnego rządu, ale przeciwnie rząd ten osłabia"; spr. sten. z 209. posiedzenia SU, 11 lutego 1921 r., ł. 52.

${ }^{82}$ Confer szerzej P.A. Tusiński Komisja Spraw Zagranicznych Sejmu Ustawodawczego 1919-1922 jako podmiot polityki zagranicznej w pierwszych latach II Rzeczypospolitej, „Wschodni Rocznik Humanistyczny", 2015, t. XII.

${ }^{83} \mathrm{~W}$ uchwale z dnia 7 listopada 1919 r. o powołaniu komisji dla zbadania stanu rzeczy w więzieniach i obozach koncentracyjnych na całym obszarze Rzeczypospolitej Polskiej i terenach wojennych znalazło się postanowienie: „Komisja ma prawo wstępu w każdej porze do więzień i obozów koncentracyjnych, do cel pojedynczych i zbiorowych. Komisja ma prawo zapoznawać się z papierami uwięzionych, żądać wyjaśnień od władz administracyjnych, cywilnych i wojskowych, od władz sądowych i od administracji więziennej”.

${ }^{84}$ Przykładowo: w rządzie I.J. Paderewskiego m.in. minister skarbu, odpowiedzialny w dużej mierze za pozyskiwanie podatków i finanse państwa, zmieniał się trzykrotnie, minister aprowizacji również trzykrotnie, a minister sprawiedliwości dwukrotnie. W rządzie W. Witosa m.in. ministrowie spraw zagranicznych, skarbu, ochrony pracy zmieniali się trzykrotnie, minister aprowizacji pięciokrotnie, a ministrowie sprawiedliwości, przemysłu i handlu, spraw wewnętrznych, spraw wojskowych — dwukrotnie.

${ }^{85}$ Jak głęboko postrzegano więzi z rządem w sferze odpowiedzialności politycznej obrazują słowa posła H. Diamanda wypowiedziane w trakcie debaty dotyczącej objęcia przez ministra skarbu administracji skarbowej na obszarze Polski, który dawniej zajęty był przez monarchię austro-węgierską. W trakcie prac sejmowych nad tą ustawą zmienił się minister skarbu — miejsce J. Englicha zajął S. Karpiński — poseł Diamand stwierdził wtedy m.in.: „Pan Minister Skarbu nie cieszy się zaufaniem całej izby. Na konferencji przewodniczących klubów podnoszono co do osoby Pana Ministra wątpliwości. Mimo to Rząd zamianował Ministra, a Sejm, Suwerenny Sejm nie wie kto został ministrem Skarbu, kto — w tem znaczeniu, że nie znamy 
nie funkcji cywilnej z dowodzeniem wojskiem i to w czasie konfliktów zbrojnych, silna grupa jego zwolenników usytuowanych w różnych klubach sejmowych, w tym w zasadzie stałe poparcie partii lewicy parlamentarnej, uniemożliwiały pociagnięcie go do odpowiedzialności parlamentarnej. Dopiero stabilizacja polityczna państwa związana z zakończeniem wojny z Rosją Radziecka, okrojenie kompetencji Naczelnika związanych z prowadzoną wojna, ale też ostry konflikt z Sejmem na tle wymuszenia upadku rządu Antoniego Ponikowskiego, doprowadził do nieudanej próby odwołania J. Piłsudskiego przez Sejm Ustawodawczy ${ }^{86}$.

Nie oznacza to jednak, żeby relacje między SU a Naczelnikiem Państwa nie były z reguły napięte, szczególnie gdy chodzi o zachowanie prawicowego, wyraźnie niechętnego Piłsudskiemu, skrzydła konstytuanty ${ }^{87}$. Animozje dotyczyły nie tylko kwestii znajdujących się stale w obszarze zainteresowania Naczelnika Państwa, ale także dziedzin, w których co prawda jego udział był znikomy czy wręcz symboliczny, ale dla jego przeciwników politycznych stanowił dogodny przyczynek do ataków ${ }^{88}$.

Odpowiedzialność parlamentarna Rady Ministrów ujawniała się w różnych postaciach. Jednym z rozwiązań, praktykowanym w zasadzie od początku obowiązywania małej konstytucji stanowiło przedkładanie przez prezydenta Ministrów exposé programowego. $Z$ reguły poprzedzała je informacja Naczelnika Państwa lub prezydenta Ministrów, odczytywana przez marszałka Sejmu, o dymisji poprzedniego rządu i powołaniu nowego gabinetu. Początkowo exposé podlegało jedynie konfrontacji z wystapieniami klubowymi, jednak bez głosowania formalnego wotum zaufania. Uważano bowiem, że skoro w Konwencie Seniorów zapadała decyzja o kandydaturze szefa rządu i całym składzie gabinetu, wykazując formalne poparcie lub neutralność większości klubów, to głosowanie takie jest zbędne ${ }^{89}$. Dopiero 16 czerwca 1922 r. na tle konfliktu z Naczelnikiem Państwa związanym z dymisją drugiego rządu A. Ponikowskiego została przesądzona kwestia udzielania inwestytury sejmowej poprzez przyjmowanie w Sejmie wotum zaufania dla nowo powstałego rządu. Pierwszym rządem,

ani poglądów, ani planów Pana Karpińskiego - a to zdaje mi się, jest rzeczą której Sejm spokojnie ścierpieć nie może". Spr. sten. z 28. posiedzenia SU, 8 kwietnia 1919 r., 1. 5-6.

${ }^{86}$ Szeroko na ten temat J. Faryś, Konflikt Naczelnika Państwa z Sejmem Ustawodawczym w 1922 roku, „Dzieje Najnowsze” 1975, nr 3; K.W. Kumaniecki, op. cit., s. 621 i n.; A. Ajnenkiel, Historia..., s. 48 i n.

${ }^{87}$ Szczególnie zajadłym krytykiem Naczelnika był poseł ks. K. Lutosławski.

${ }^{88} \mathrm{~Np}$. w trakcie debaty nad ustawą o ubezpieczeniach państwowych i Państwowej Dyrekcji Ubezpieczeń poseł A. Wierzbicki krytykował rozwiązanie zaproponowane przez sejmową Komisję Administracyjna, przewidujące, że prezes Zarządu Dyrekcji Ubezpieczeń będzie powoływany przez Naczelnika Państwa na wniosek ministra skarbu, uznając, że daje to mu swoistą nietykalność, uniemożliwiającą jego odwołanie w przypadku wykazania mu niekompetencji; spr. sten. z 209. posiedzenia SU, 11 lutego 1921 r., ł. 40. Podobny charakter miała debata nad broszurą posła J. Zamorskiego, atakującą J. Piłsudskiego; confer rezolucję z 30 listopada 1921 r. i spr. sten. z 266. posiedzenia SU z tego dnia, 1. 20-48.

89 Jednak posiadanie zaufania przez cały okres działalności rządu i poszczególnych jego członków było traktowane jako warunek sine qua non. W efekcie tego niemal przez cały okres ich działalności byli narażeni na systematyczne ,sprawdzanie” spełnienia tego warunku, poprzez różnorodne środki parlamentarne, niekoniecznie ukierunkowane wprost na weryfikację zaufania izby, ale mające weryfikować, na ile każde z konkretnych działań rządu i ministrów ma poparcie większości parlamentarnej. To zaś powodowało, że rząd i jego członkowie byli zmuszeni do kalkulowania swoich działań pod kątem ewentualnej utraty zaufania. 
który formalnie wystapił w takiej sytuacji o wotum zaufania, był gabinet A. Śliwińskiego, któremu zresztą go odmówiono.

Formalne głosowanie nad wotum nieufności było rzadkością, gdyż kres rządu następował w wyniku nie tyle głosowania, co w drodze kalkulacji głosów popierających gabinet, głosów neutralnych oraz jego przeciwników. W przypadku wyraźnej mniejszości tych pierwszych, gabinet był podawany do dymisji. Tak wydarzyło się w przypadku rządu I.J. Paderewskiego, L. Skulskiego, W. Grabskiego, W. Witosa, pierwszego i drugiego gabinetu A. Ponikowskiego. Z reguły jednak prawdziwą przyczyną upadku gabinetu był rozpad koalicji, ujawniający się niekiedy przy okazji upadku istotnego projektu rządowego w Sejmie. Przykładowo, rząd L. Skulskiego za próbnik dla swej dalszej egzystencji uznał uchwalenie ustawy o sekwestrze, a gdy została ona odrzucona przez większość domagającą się wolnego obrotu handlowego produktami rolnymi, podał się do dymisji. Z kolei pierwszy rząd A. Ponikowskiego podał się do dymisji na skutek sporu między prawicą a lewicą sejmową oraz wobec zachodnich nacisków dyplomatycznych i Naczelnika Państwa w kwestii statusu Wileńszczyzny i formuły jej włączenia do Polski. Brak zaufania wobec członków rządu był często manifestowany w innych formach. Jedną z nich był brak poparcia dla polityki ministra, wyraźnie okazywany przez komisję sejmowa, organ z reguły kluczowy dla wytworzenia dobrych relacji między konstytuantą a ministrem. Manifestowane odrzucanie rekomendowanej przez danego ministra polityki lub popieranego projektu ustawy kończył się ustępstwem członka rządu lub jego dymisją ${ }^{90}$, jak zdarzyło się w przypadku ministra Eustachego Sapiehy. Inną formą dezawuowania członka gabinetu było odrzucenie przez komisję lub Sejm przedłożonego sprawozdania lub odpowiedzi na interpelację ${ }^{91}$.

Rządy w okresie obowiązywania małej konstytucji nie były w stanie wytworzyć spójni ideowo-programowej zarówno ze względu na oparcie ich na kruchych koalicjach parlamentarnych, jak i konieczność formowania rządów o genezie pozaparlamentarnej, np. Władysława Grabskiego, dwa gabinety A. Ponikowskiego, Artura Śliwińskiego czy Juliana Nowaka. Z oczywistych względów zarówno te gabinety, jak i rządy koalicyjnej większości, które jednak z biegiem czasu stawały się gabinetami mniejszościowymi, spotykały się w SU z wachlarzem postaw — najczęściej dwie mniejszościowe grupy zwolenników i przeciwników rządu oraz pewna część ugrupowań zaledwie tolerujących rząd, zazwyczaj ze względów taktycznych, aby nie doszło do przesilenia, a w jego efekcie utworzenia gabinetu sformowanego przez przeciwników politycznych ${ }^{92}$. Rządy te z reguły dość szybko poddawane były zmasowanej kry-

${ }^{90}$ Znany był przypadek ministra spraw zagranicznych E. Sapiehy, któremu członkowie Komisji Spraw Zagranicznych odmówili zaufania, powiadamiając o tym premiera W. Witosa; szerzej Ministrowie spraw zagranicznych II Rzeczypospolitej, red. J. Pajewski, Szczecin 1992, s. 77 i n.

${ }_{91}$ Tak wydarzyło się w związku z rozpatrywaniem sprawy Dojlid, gdy prezes Urzędu Ziemskiego i członek gabinetu A. Ponikowskiego W. Kiernik podał się do dymisji na skutek odrzucenia przez Sejm jego odpowiedzi na interpelację posłów Związku Ludowo-Narodowego; vide szerzej spr. sten. z 296. posiedzenia SU, 4 kwietnia 1922 r., 1.72 i n.

${ }_{92}$ M. Bobrzyński, op. cit., s. 101 i n., opisując formowanie rządów w tym czasie, napisał: „Szukano chwilowych kompromisów. Rząd taki nie złączony ze sobą naprawdę programem wspólnym, nie miał wa- 
tyce, wychodzącej także od partii wspierających rząd, np. gdy nie zgadzały się z propozycją wysuwaną przez członka rządu popieranego przez inną partię koalicyjną. Inna rzecz, że rządy pozaparlamentarne nie podejmowały projektów, które mogły go antagonizować z Sejmem, prowadząc politykę kunktatorską ${ }^{93}$.

Na niekomfortowe położenie rządów wobec SU zwracał uwagę m.in. poseł I. Daszyński: „Spytacie dlaczego wszystkie gabinety zrażone waszą wrzawa, krzykami i obelgami rzucają te rządy? Dlatego, bo powiadają: Nie chcemy wiecznie stać pod pręgierzem u swoich i u obcych; nie możemy nic zrobić, bo każdy plan jest w tej chwili pokiereszowany, opluty przez was, przez waszą prasę, wasze zgromadzenia i waszych ludzi" ${ }^{94}$. Wsparcie lub zaledwie tolerancja dla rządów z reguły wynikała z faktu ulokowania w nich osób, które odpowiadały za sprawy bliskie danemu stronnictwu, ale udzielanie wsparcia dla konkretnego ministra nie przenosiło się na poparcie dla całego gabinetu, np. w rządzie I.J. Paderewskiego człowiekiem zaufania endecji był sam prezydent Ministrów czy minister skarbu Leon Biliński ${ }^{95}$, a w gabinecie L. Skulskiego reprezentantem Narodowego Zjednoczenia Ludowego był sam premier oraz ministrowie Władysław Seyda i W. Grabski, gdy Andrzej Kędzior i F. Bardel reprezentowali PSL „Piast”. Następstwem tego było atomizowanie się rządu, brak solidarności gabinetowej oraz konflikty między ministrami. Stosunkowo szybko dostrzegł to poseł. W. Witos, który w trakcie posiedzenia Sejmu mówił: „Na różnych komisjach [...] widzieliśmy, że przedstawiciele poszczególnych ministerstw występowali przeciwko sobie, [...] że rząd nie idzie razem, że nie ma programu, że nie panuje tam jednolitość poglądów, czyli że robota musi być chaotyczna" ${ }^{\prime 66}$. W sytuacji państwa wymagającego długoletnich programów odbudowy szeregu dziedzin życia publicznego oraz konsekwencji w ich realizacji, przynosiło to zgubne efekty, które poseł Edward Dubanowicz, wybitny konstytucjonalista nazwał rządzeniem „od wypadku do wypadku”97.

Wielokrotnie zwracano uwagę na niewykonywanie ustaw przez rząd. Słynne były problemy z wdrożeniem reformy rolnej, co wzbudzało aktywność (choć idącą w różnych kierunkach) zarówno stronnictw chłopskich, jak i obozu prawicowego. Innym przykładem było niewykonywanie ustawy inwalidzkiej z 18 marca 1921 r., co w świetle ustaleń komisji sejmowej było m.in. wynikiem nieuzgodnienia stanowisk właści-

runków trwałości, bo każda ważniejsza sprawa, wywołując sprzeczne żądania stronnictw wchodzących w skład koalicji, osłabiała i rozkładała rząd. Pokusa dostania się do władzy i uzyskania choćby na krótki czas wpływu na administrację i różnych korzyści dla stronnictwa i dla jego wyborców była jednak tak silna, że próby tworzenia takiego rządu i kompromisów programowych pojawiały się nieustannie".

${ }_{93} \mathrm{~Np}$. poseł W. Witos, krytykując rząd A. Ponikowskiego, zauważył, że jego gabinet kierował się zasada, że ,[...] w najważniejszych sprawach nie powinien zajmować żadnego stanowiska i że może usunać się od rozwiązywania wszelkich trudności. To zrodziło chwiejność, niezdecydowanie, brak myśli i wyraźnego kierunku"; spr. sten. z 302. posiedzenia SU, 4 maja 1922 r., 1. 12.

${ }_{94}$ Spr. sten. z 248. posiedzenia SU, 30 września 1921 r., ł. 46.

${ }_{95}$ Symptomatyczne było jego pierwsze wystapienie sejmowe 3 października 1919 r., kiedy wprost stwierdził, że członkostwo w rządzie ma ,do zawdzięczenia szanownym stronnictwom tego Sejmu, które wyraziły życzenie, ażebym objął urząd Ministra Skarbu"; spr. sten. z 86. posiedzenia SU z tego dnia, ł. 6.

${ }_{96}$ Spr. sten. ze 103. posiedzenia SU, 25 listopada 1919 r., 1. 41. Podobnie na tym samym posiedzeniu podsumowujący dokonania rządu I.J. Paderewskiego wypowiadał się poseł L. Skulski, ł. 53-54.

${ }^{97}$ Spr. sten. z 248. posiedzenia SU, 30 września 1921 r., ł. 32. 
wych ministerstw ${ }^{98}$. Jednak przyczyny tego stanu były różne, tkwiące zarówno po stronie gabinetu, jak i poza nim. Kolejni ministrowie zainteresowani byli własnymi projektami, nie zaś kontynuowaniem kierunków zainicjowanych przez poprzedników, czego zresztą często od nich oczekiwały siły wspierające rząd. Niekiedy taka postawa wynikała z faktu, że większość opowiadająca się za uchwaleniem ustawy szybko się rozpadała, co sprawiało, że tracono zainteresowanie dla realizacji tejże.

Rezolucje SU, choć licznie podejmowane, były traktowane wybiórczo przez rząd i poszczególnych ministrów ${ }^{99}$. Określały zadania indywidualne poszczególnych członków rządu ${ }^{100}$. Odnosiły się one często do spraw z zakresu zwykłego kierownictwa podległej administracji ${ }^{101}$, interwencji w sprawach jednostkowych ${ }^{102}$. Często też SU, mimo swej formalnie kreatorskiej roli względem polityki państwa, wzywał gabinety i ministrów do przedstawiania programów działania w wybranych obszarach polityki państwa ${ }^{103}$.

Mała konstytucja nie stała się też impulsem dla racjonalizacji organizacji rządu i administracji rządowej. Stosunkowo często podnoszono zarzut rozbudowania ponad miarę różnych agend rządowych ${ }^{104}$, ich niewydolności wynikającej często z braku środków finansowych ${ }^{105} \mathrm{i}$ wspomnianej walki wewnętrznej w rządzie. Dekret wydany przez Radę Regencyjną 3 stycznia 1918 r. o tymczasowej organizacji władz naczelnych w Królestwie Polskim w efekcie praktyki ustrojowej stawał się coraz bardziej zawodnym narzędziem regulującym pracę gabinetu. W wyniku konfliktów politycznych w rządzie, ale też niesprzyjających warunków parlamentarnych, funkcjonowanie gabinetu oddalało się od dekretowego wzorca. Koalicyjna struktura partyjna części gabinetów lub pozaparlamentarny charakter pozostałych sprawiały, że ministrowie często dochodzili do porozumienia z poszczególnymi klubami poselskimi, a nawet ich częścia, poza świadomością rządu. To dodatkowo atomizowało gabinet i osłabiało po-

98 Spr. sten. z 262. posiedzenia SU, 18 listopada 1921 r., ł. 43-70.

99 Na jednym z posiedzeń Sejmu poseł ks. K. Sobolewski stwierdził: „Komisja Administracyjna wie ze smutnego trzyletniego doświadczenia Wysokiego Sejmu, że większość rezolucji uchwalonych przez Sejm, stała się przysłowiowym grochem o ścianę Rządu, ale niechaj i Polska wie, że Sejm spełnia swój obowiązek"; spr. sten. z 255. posiedzenia SU, 18 października 1921 r., 1. 10. Na 123. posiedzeniu Sejmu 24 lutego 1920 r. poseł S. Rottermund zwrócił uwagę na niewykonanie rezolucji z maja 1919 r. w sprawie rozgraniczenia kompetencji dwóch ministerstw.

${ }_{100}$ Np. rezolucja z 18 listopada 1921 r. wzywająca do przedstawienia Sejmowi projektu ustawy dotyczącej szpitalnictwa, rezolucje z 2 grudnia 1921 r. w sprawie aktywizacji w województwach i powiatach komitetów wałowych oraz skierowania do Sejmu projektu ustawy o Szkole Nauk Politycznych.

$101 \mathrm{~Np}$. rezolucja z 18 października 1921 r. wzywająca rząd do skutecznej ochrony granic celnych, czy cykl 7 rezolucji z 20 stycznia 1922 r. dotyczących organizacji służby celnej, w tym jej podległości.

$102 \mathrm{~Np}$. cykl rezolucji z 21 października 1921 r. odnoszących się do Muzeum w Rapperswilu, rezolucja z 25 listopada 1921 r. w sprawie sprzedaży drutu kolczastego.

${ }_{103} \mathrm{~Np}$. na 275. posiedzeniu SU 17 grudnia 1921 r. przyjęto rezolucję wzywającą ,rząd do przestawienia planu racjonalnego i celowego działania w kierunku popierania twórczości naukowej i środowisk nauki, jej twórców i krzewicieli”.

104 Np. w dniu 27 stycznia 1920 r. SU podjął rezolucję: „Wzywa się rząd, aby w ciagu 2 miesięcy przedstawił Sejmowi projekt reorganizacji urzędów państwowych celem zmniejszenia liczby urzędników do norm koniecznych". Confer M. Bobrzyński, op. cit., s. 131 i n.

$105 \mathrm{~Np}$. istnienie równolegle dwóch dublujących swe funkcje urzędów, jak urząd melioracji i urząd torfowy, spr. sten. z 109. posiedzenia SU, 22 lipca 1925 r., ł. 16. 
zycję jego szefa. Niekiedy konstytuanta wyrażała oczekiwania względem struktury rządu i administracji, poparte raczej wiedzą ogólną niż rzetelnymi badaniami ${ }^{106}$. Próba uporządkowania tego stanu rzeczy została podjęta przez rząd L. Skulskiego, który przedłożył projekt ustawy o zakresie działania władz naczelnych. Stało się to jednak w przededniu upadku jego rządu, i choć projekt trafił do sejmowej Komisji Konstytucyjnej, nigdy nie został uchwalony. Warto jednak wskazać, że próbował on w formie normatywnej zaradzić dysfunkcjonalności ówczesnych rządów. Wprowadzał nowe — w świetle wspomnianego dekretu Rady Regencyjnej — zasady głoszące, że prezydent Ministrów czuwa nad jednolitością ogólnej polityki rządu, sprawuje nadzór nad działalnością poszczególnych ministrów oraz przestrzega granic ich kompetencji.

Szczególną pozycję w faktycznym systemie rządów istniejącym w okresie obowiązywania małej konstytucji zajmował Naczelnik Państwa. Niewatpliwie wyłamał się z ciasnych ram nałożonych przez uchwałę Sejmu, na co złożyło się wiele przyczyn. Dla sporej części społeczeństwa oraz klasy politycznej J. Piłsudski był postacią charyzmatyczną, owianą nimbem chwały za rolę, jaką odegrał w trakcie I wojny światowej i odzyskiwania niepodległości, a z biegiem czasu za zasługi w wojnie polsko-bolszewickiej. Towarzyszył temu twardy charakter ${ }^{107}$, przekonanie do własnych racji oraz oddane grono współpracowników, w tym także adherentów politycznych usytuowanych w różnych klubach parlamentarnych. Był konsekwentny w działaniu przy sprawowaniu urzędu, co po części było skutkiem jego natury, ale też wynikało z przewagi, jaką posiadał organ jednoosobowy nad kolegialnymi, silnie uwikłanymi w skomplikowany wewnętrzny proces decyzyjny. Należy pamiętać, że Naczelnik Państwa był jednocześnie Naczelnym Wodzem, odpowiadającym za działania wojenne na znacznym obszarze państwa, a tym samym za zarząd tą częścią terytorium ${ }^{108}$. Implikowało to zawężenie terytorialne oddziaływania SU, co zresztą prowadziło do licznych prób tego kontestowania w pracach Sejmu. Skupienie się Piłsudskiego na kwestiach obronności i ścisły związek z siłami zbrojnymi nie ustały wraz z formalnym zakończeniem działań wojennych, gdyż na początku 1921 r. powołał Ścisłą Radę Wojenną, która w istocie autonomizowała problematykę obronną i wojenną względem rządu, podporządkowując przy tym ministra spraw wojskowych jako jej organ wykonawczy ${ }^{109}$. Sam Piłsudski był niemal bezustannie przedmiotem sporów politycznych w SU ${ }^{110}$, jednak skala poparcia dla niego wśród ugrupowań parlamentarnych, choć zmienna i uzależniona zarówno od przedmiotu ocen, jak

${ }^{106}$ Wystapienie i wniosek posła Suligowskiego i innych posłów w sprawie reformy administracji państwowej, spr. sten. z 249. posiedzenia SU, 1 października 1921 r., 1. 51 i n.

107 Zwracał na to uwagę także polityczny przeciwnik Naczelnika, poseł S. Głąbiński, op. cit., s. 452.

108 Problem ten ujawnił się w trakcie ekspresowych prac nad małą konstytucja, gdyż Piłsudski kontestował jej postanowienia przyznające mu rolę wykonawcy uchwał Sejmu w sprawach wojskowych. Wobec powyższego wszystkie ugrupowania zasiadające w Konwencie Seniorów przyjęły w protokole ze swego posiedzenia uzgodnienie - formalnie pozbawione mocy prawnej, gdyż niemieszczące się w samym akcie - głoszace, że pod ten punkt nie podpadają wojskowe rozporządzenia strategiczne lub taktyczne; szerzej M. Pietrzak, op. cit., s. 45 i n.

109 Confer J. Wołpiuk, Naczelnik Państwa 1918-1922. Przedprezydencka forma władzy państwowej, „Przegląd Sejmowy” 2006, nr 6, s. 36 i n.

110 Por. W. Wołpiuk, op. cit., s. 37 i n. i cyt. tam literatura 
i konkretnych okoliczności, uniemożliwiała podjęcie silniejszych środków działania wobec niego. Wspomniany wcześniej konflikt z Sejmem na tle interpretacji uprawnień Naczelnika Państwa w zakresie powoływania rządu, szeroko opisywany w literaturze, również nie doprowadził do przesilenia. Potwierdził raczej istnienie pewnej równowagi sił między silną pozycją i kompetencjami, lecz słabą zdolnością do ich egzekucji Sejmem Ustawodawczym, a formalnie drugorzędnie usytuowanym Naczelnikiem Państwa, czerpiącym jednak swą siłę zarówno z poparcia społecznego, jak i kręgów politycznych i wojskowych. Często równoważące się oddziaływania między Sejmem a Naczelnikiem Państwa, występujące od początku obowiązywania małej konstytucji sprawiły, że J. Piłsudski zachowywał faktyczny wpływ na kształt rządu. Choć formalnie kluczem poszukiwania przez Sejm nowego szefa rządu było sondowanie poparcia parlamentarnego gabinetu $^{111}$, to stanowisko Belwederu było istotną wskazówką, często niewyrażoną wprost przy poszukiwaniu optymalnego kandydata, gwarantującego możliwą współpracę z Naczelnikiem. Uwzględnianie stanowiska J. Piłsudskiego przychodziło nolens volens łatwiej, gdy ugrupowania sejmowe nie osiagały porozumienia w tej kwestii, a argument poparcia lub jego braku ze strony Belwederu urastał do roli przesłanki przesądzającej o sformowaniu gabinetu lub poniechania tego. Jest charakterystyczne, że nawet dwaj szefowie rządów parlamentarnych (L. Skulski, W. Witos) uważani byli za dobrze współpracujących z głową państwa, za co czyniono im zarzuty. W efekcie nieraz udawało się wywrzeć wpływ na powołanie w skład rządu oddanych mu ministrów, np. S. Wojciechowski został ministrem spraw wewnętrznych w rządach I.J. Paderewskiego i L. Skulskiego, a K. Bartel ministrem kolei w rządach L. Skulskiego i W. Witosa.

Szczególny, choć także nieformalny wpływ uzyskał J. Piłsudski na obsadę stanowiska ministra spraw wojskowych ${ }^{112}$, co było mu pomocne w sprawowaniu funkcji Naczelnego Wodza i umacnianiu wpływów w wojsku. Równie nieformalnie, choć wyraźnie dla opinii publicznej Naczelnik Państwa oddziaływał na obsadę stanowiska ministra spraw zagranicznych ${ }^{113}$. Jego wpływ na priorytety polityki zagranicznej wynikał po części z prowadzonych działań wojennych, ale też koniecznego budowania relacji międzynarodowych, wzmacniających pozycję Polski w sferze ekonomicznej, bezpieczeństwa i obrony, a więc wyraźnie wykraczał poza wymagania związane ze wsparciem głowy państwa ${ }^{114}$. W tych dwóch obszarach można po części zgodzić się

111 Szeroko na ten temat M. Pietrzak, op. cit., s. 135 i n.

112 Powołany na to stanowisko w lutym 1919 r. gen. J. Leśniewski sprawował je do sierpnia 1920 r. w kolejnych czterech gabinetach (I.J. Paderewskiego, L. Skulskiego, W. Grabskiego i W. Witosa), a jego zastępcą (osobą faktycznie kierującą resortem) był najbliższy współpracownik Naczelnika gen. K. Sosnkowski, który został w sierpniu 1920 r. jego następcą i kierował nieprzerwanie resortem w kolejnych gabinetach do 1924 r.

113 Do ministrów związanych z Naczelnikiem należeli S. Patek i E. Sapieha, którzy kolejno kierowali resortem od grudnia 1919 r. do maja 1921 r. oraz G. Narutowicz (czerwiec-grudzień 1922 r.). Jego antagonistą politycznym, a jednocześnie ministrem osłabiającym wpływ J. Piłsudskiego na politykę zagraniczną był K. Skirmunt, z którym ostry konflikt doprowadził do wymuszenia upadku rządu A. Ponikowskiego. Confer Ministrowie..., Szczecin 1992.

114 Przewodniczący Komisji Spraw Zagranicznych S. Grabski przyznał, że odbywał regularne spotkania z Naczelnikiem Państwa w celu omówienia kwestii stojących w jej porządku dziennym, często ustalając z nim wcześniej problematykę prac komisji, confer S. Grabski, Pamiętniki, t. II, Warszawa 1989, s. 114. 
z opinią S. Rogowskiego o wielotorowości polityki prowadzonej przez zasadnicze organy naczelne RP. Dolegliwa i nieustanna kontrola polityki zagranicznej dokonywana przez komisję sejmowa, liczne próby ingerencji Sejmu w tej sferze, odbywane niekiedy przy okazji ratyfikacji umów międzynarodowych, wreszcie usiłowanie — z reguły nieudane, ze względu na postawę J. Piłsudskiego — ingerencji w kierowanie siłami zbrojnymi stanowiły codzienność działania najwyższego organu państwowego. Z kolei polityka rządu, z reguły meandryczna, była pochodną realnych potrzeb i możliwości działania państwa z próbą zaspokojenia politycznych ambicji stronnictw sejmowych oraz uwzględniania z reguły twardo stawianych oczekiwań Naczelnika Państwa. Opisana wcześniej słabość wewnętrzna Sejmu, niezdolność do wypracowania konsekwentnej polityki państwa w obszarze obronności, bezpieczeństwa i stosunków zagranicznych, przenosząca się na kolejne rządy, była wykorzystywana przez głowę państwa dzięki stałości jego poglądów, konsekwencji realizacji swych planów i umiejętnościom taktycznym wykazywanym w relacjach z pozostałymi organami. W efekcie mimo formalnego braku konstytucyjnych uprawnień do kształtowania polityki zagranicznej, obronnej i bezpieczeństwa, Naczelnikowi Państwa udało się w tym zakresie równoważyć wpływy pozostałych organów naczelnych ${ }^{115}$.

\section{PODSUMOWANIE}

W czasie jednego z posiedzeń SU, ponad rok od przyjęcia małej konstytucji poseł endecki S. Głąbiński zauważył: „Sądzę, że Sejm nie korzysta z tych praw jakie ma i jakie sam sobie nadał uchwałą z 20 lutego, ogłosiwszy się sejmem suwerennym. Można by wskazać na postępowanie Sejmu w ostatnich czasach, z którego się okazuje, że znaczną część suwerenności Sejm sam ustępuje i nie korzysta z tych praw, jakie posiada sejm konstytucyjny" "116. W efekcie bowiem przyjęta w małej konstytucji forma rządów, bliska rządom zgromadzenia ${ }^{117}$, uległa ewolucji w kierunku rządów parlamentarnych sprzed ery ich racjonalizacji. Wytworzone elementy równowagi między SU a Naczelnikiem Państwa, niepełne podporządkowanie Rady Ministrów konstytuancie i uległość rządu w pewnym zakresie wobec Naczelnika Państwa to elementy praktyki ustrojowej, które rozwinęły się wbrew zamierzeniom twórców małej konstytucji. Niezdolność SU do egzekwowania swej pozycji ustrojowej dezorganizowała pracę rządu, co w efekcie sprawiło, że oba te organy nie były zdolne do wykonania ról ustrojowych, powierzonych im przez małą konstytucję. Słabości obu organów wykorzystał J. Piłsudski, zachowując dzięki temu liczącą się, wcale niedrugorzędną pozycję ustrojową.

115 Confer S. Rogowski, Praktyka konstytucyjna w okresie obowiazywania Matej Konstytucji z 1919 r., [w:] Mate Konstytucje..., s. 42 i n.

${ }_{116}$ Parlamentaryzm II Rzeczypospolitej, Warszawa 1975; spr. sten. z 145. posiedzenia SU, 7 maja 1920 r., 1. 45.

${ }^{117}$ Charakterystyka tej formy rządów zawierała się także w zwięzłej formule rządów sejmowych użytej przez W. Komarnickiego, op. cit., s. 73 i n. Formuła ta, odpowiednik rządów zgromadzenia, wskazywała, że nie był to system rządów parlamentarnych, nawet w „,skrajnej postaci”, choćby ze względu na kluczowe założenie ustrojowe, czyli odrzucenie zasady podziału władz. Confer także P. Sarnecki, Założenia ,rzqdów zgromadzenia" i możliwości ich adaptacji do przyszłej konstytucji RP, [w:] Konstytucyjne systemy rzq̨ów. Możliwości adaptacji do warunków polskich, red. M. Domagała, Warszawa 1997, s. 138 i n. 
Na taki kształt relacji między SU, Naczelnikiem Państwa i rządem złożyło się wiele przyczyn. Podobnie jak w wielu wspomnianych wcześniej państwach przekonanie o tym, że stan podwyższonej aktywności politycznej obywateli będzie stałym elementem pejzażu politycznego odradzającego się państwa, znajdowało - naturalny w tych warunkach - wyraz w postaci uprzywilejowanej pozycji konstytuanty. Jednak warunki zarówno zewnętrzne, jak i wewnętrzne jej funkcjonowania uniemożliwiły w praktyce spełnienie roli, do jakiej predestynowała. Jej wewnętrzne podziały i coraz bardziej agresywny sposób ich artykułowania oraz niezdolność do konsolidacji nastawionych z reguły konfrontacyjnie ugrupowań sejmowych, silnie osłabiały jej zdolność do determinowania działalności pozostałych organów systemu rządów. W efekcie ramy prawne małej konstytucji, otwierające drogę do niczym nieskrępowanej dominacji SU, zostały wykorzystane głównie przez Naczelnika Państwa, po stronie którego obok osobistych zdolności i predyspozycji, stała też wierna i ciągle zwiększająca się grupa zwolenników, w tym także wśród parlamentarzystów. Silnie motywowany do działania Naczelnik Państwa w konfrontacji z niezdolnym do wykorzystania swej pozycji SU, uzyskiwał na tyle istotny wpływ na bieg spraw państwowych, że wielokrotnie potrafił równoważyć oddziaływania konstytuanty. Niemal chroniczny brak większości parlamentarnej i stan niezorganizowanego pluralizmu partyjnego w SU pozbawiał rząd silnego w nim oparcia. W tej sytuacji oddziaływanie Naczelnika Państwa wzmocnionego dodatkowo pozycją Naczelnego Dowódcy, biorącego na siebie ciężar rozwiązania najtrudniejszego zadania stojącego przed państwem, jakim była obrona jego niepodległości, dodatkowo krępowało swobodę działalności rządu.

Wraz z odzyskaniem niepodległości Polska poznawała funkcjonowanie systemu rządów, odległego od dotychczasowej praktyki znanej państwom zaborczym. Brakowało w nim czynnika nadrzędnego, porządkującego działanie innych podmiotów reżimu politycznego, a konieczne stawało się zaakceptowanie pluralizmu społecznego i politycznego i oparcie systemu rządów na cierpliwie osiaganym kompromisie.

\section{BIBLIOGRAFIA}

\section{ŹRÓDŁA}

Dekret Rady Regencyjnej z dnia 3 stycznia 1918 r. o tymczasowej organizacji Władz Naczelnych w Królestwie Polskiem, Dz.P.P.P. z 1918 r. nr 1, poz. 1.

Dekret Józefa Piłsudskiego z dnia 14 listopada 1918 r., Dz.U. z 1918 r. nr 17, poz. 40.

Dekret Tymczasowego Naczelnika Państwa o najwyższej władzy reprezentacyjnej Republiki Polskiej z dnia 22 listopada 1918 r., Dz.U. z 1918 r. nr 17, poz. 41.

Uchwała Sejmu z dnia 20 lutego 1919 r. o powierzeniu Józefowi Piłsudskiemu dalszego sprawowania urzędu Naczelnika Państwa, Dz.U. z 1919 r. nr 19, poz. 226.

Sprawozdania stenograficzne Sejmu Ustawodawczego z posiedzeń w latach 1919-1922, $1-342$.

\section{PIŚMIENNICTWO}

Ajnenkiel A., Spór o model parlamentaryzmu polskiego do roku 1926, Książka i Wiedza, Warszawa 1972. 
Ajnenkiel A., Parlamentaryzm II Rzeczypospolitej, Wiedza Powszechna, Warszawa 1975.

Ajnenkiel A., Historia sejmu polskiego, t. II, cz. 2, PWN, Warszawa 1989.

Ajnenkiel A., Sejm jako czynnik integracji narodu i państwa, [w:] Sejmy Drugiej Rzeczypospolitej, red. A. Zakrzewski, Ludowa Spółdzielnia Wydawnicza, Warszawa 1990.

Bobrzyński M., Wskrzeszenie państwa polskiego. Szkic historyczny, t. II, Krakowska Spółka Wydawnicza, Kraków 1920.

Ciświcki T., O Naczelniku Państwa i Prezydencie Rzeczypospolitej Polskiej. Studium prawnopolityczne, Wydawnictwo Fiszer i Majewski, Poznań 1922.

Cybichowski Z., Polskie prawo państwowe, cz. I, Wydawnictwo Seminarium Prawa Publicznego Uniwersytetu Warszawskiego, Warszawa 1925.

Faryś J., Konflikt Naczelnika Państwa z Sejmem Ustawodawczym w 1922 roku, „Dzieje Najnowsze" 1975, nr 3.

Głąbiński S., Wspomnienia polityczne, Drukarnia i Księgarnia, Pelpin 1939.

Goclon J., Rzad Ignacego Jana Paderewskiego. Geneza, skład osobowy i działalność (16 stycznia 1919-9 grudnia 1919), „Acta Universitatis Lodziensis. Folia Historica” 2011, nr 86.

Goclon J., Rząd Jędrzeja Moraczewskiego 17 XI 1918-16 I 1919 (struktura, funkcjonowanie, dekrety), „Przegląd Nauk Historycznych” 2009, t. VIII, nr 2.

Goclon J., Rzqd Leopolda Skulskiego (13 XII 1919 r.-9 VI 1920 r.) sktad, funkcjonowanie i jego polityka wschodnia, „Acta Universitatis Lodziensis. Folia Historica” 2012, nr 88.

Grabski S., Pamiętniki, t. II, Czytelnik, Warszawa 1989.

Górecki D., Powstanie władz naczelnych w odradzajacej się Polsce (1914-1919), „Acta Universitatis Lodziensis. Folia Iuridica" 1983, nr 13.

Hass L., Do genezy złudzeń parlamentarnych w Polsce międzywojennej (Sejm i głosowanie powszechne w propagandzie politycznej Królestwa 1915-1918), „Kwartalnik Historyczny” 1972, t. LXXIX, nr 1.

Komarnicki W., Polskie prawo polityczne, Księgarnia F. Hoesicka, Warszawa 1922.

Kraczkowski R., Mała Konstytucja z 20 lutego 1919 r., [w:] Małe Konstytucje. Ustawy zasadnicze okresów przejściowych 1919-1947-1992, red. R. Jastrzębski. M. Zubik, Wydawnictwo Sejmowe, Warszawa 2014.

Krukowski S., Mała Konstytucja z 1919 r., [w:] Konstytucje Polski, red. M. Kallas, PWN, Warszawa 1990.

Krukowski S., Geneza konstytucji z 17 marca 1921 r., Ludowa Spółdzielnia Wydawnicza, Warszawa 1977.

Kulesza W.T., Uchwała Sejmu Ustawodawczego z dnia 20 lutego 1919 r. o powierzeniu Józefowi Pitsudskiemu dalszego sprawowania urzędu Naczelnika Państwa, „Przegląd Sejmowy" 2007, nr 5.

Kumaniecki K.W., Odbudowa państwowości polskiej. Najważniejsze dokumenty 1912-styczeń 1924, Księgarnia J. Czerneckiego, Warszawa-Kraków 1924.

Malec D., Sejm Ustawodawczy 1919-1922. W 90. rocznice pierwszego posiedzenia, „Przegląd Sejmowy" 2009, nr 1.

Ministrowie spraw zagranicznych II Rzeczypospolitej, red. J. Pajewski, Polskie Pismo i Książki, Szczecin 1992.

Pajewski J., Budowa Drugiej Rzeczypospolitej 1918-1926, Wydawnictwo Poznańskie, Poznań 2007.

Pietrzak M., Parlament w systemie organów państwowych, [w:] Sejmy Drugiej Rzeczypospolitej, red. A. Zakrzewski, Ludowa Spółdzielnia Wydawnicza, Warszawa 1990. 
Próchnik A., Pierwsze piętnastolecie Polski niepodległej, Państwowe Wydawnictwo Naukowe, Warszawa 1983.

Rogowski S., Praktyka konstytucyjna w okresie obowiazywania Małej Konstytucji z 1919 r., [w:] Małe Konstytucje. Ustawy zasadnicze okresów przejściowych 1919-1947-1992, red. R. Jastrzębski, M. Zubik, Wydawnictwo Sejmowe, Warszawa 2014.

Rostworowski M., Wytyczne konstytucji polskiej, Krakowska Spółka Wydawnicza, Kraków 1919.

Sarnecki P., Założenia , rządów zgromadzenia” i możliwości ich adaptacji do przyszłej konstytucji RP, [w:] Konstytucyjne systemy rząów. Możliwości adaptacji do warunków polskich, red. M. Domagała, Wydawnictwo Sejmowe, Warszawa 1997.

Sarnecki P., Zasady ustrojowe odradzającej się Polski, „Przegląd Sejmowy” 1998, nr 5.

Tusiński P.A., Komisja Spraw Zagranicznych Sejmu Ustawodawczego 1919-1922 jako podmiot polityki zagranicznej w pierwszych latach II Rzeczypospolitej, „Wschodni Rocznik Humanistyczny" 2015, t. XII.

Wasik Z., Pozycja komisji parlamentarnych pod rzadami Konstytucji marcowej, Wydawnictwo Uniwersytetu Mikołaja Kopernika, Torun 1981.

Wątor A., Gabinet Leopolda Skulskiego, tenże: Gabinet Wincentego Witosa, [w:] Gabinety Drugiej Rzeczypospolitej, red. J. Pajewski, Likon, Szczecin-Poznań 1991.

Witkowski Z., Prezydent Rzeczypospolitej Polskiej 1921-1935, PWN, Warszawa-Poznań 1987.

Witos W., Moje wspomnienia, t. II, Instytut Literacki, Paryż 1964.

Wołpiuk J., Naczelnik Państwa 1918-1922. Przedprezydencka forma władzy państwowej, „Przegląd Sejmowy" 2005, nr 6. 